\title{
A COMPARATIVE PERSPECTIVE \\ ON THE EVOLUTION OF ROMANCE CLAUSAL STRUCTURE
}

\section{SAM WOLFE, ST JOHN'S COLLEGE, UNIVERSITY OF CAMBRIDGE}

The article presents a comparative analysis of the diachronic evolution of Romance clausal structure from Classical Latin through to the late medieval period, with particular reference to the Verb Second (V2) property). In the medieval period three distinct diachronic stages can be identified as regards V2: a C-VSO stage, attested in Old Sardinian, a 'relaxed' V2 stage across Early Medieval Romance and maintained into 13th and 14th century Occitan and Sicilian, and a 'strict' V2 stage attested in 13th and 14th century French, Spanish and Venetian. The C-VSO grammar found in Old

Sardinian is a retention of the syntactic system attested in late Latin textual records, itself an innovation on an 'incipient V2' stage found in Classical Latin where V-to-C movement and XPfronting receive a pragmatically or syntactically marked interpretation.

\section{INTRODUCTION ${ }^{1}$}

\subsection{Background}

Despite a vast literature on the clausal structure of Latin (Pinkster 1990; Bauer 2009; Spevak 2010; Danckaert 2012; Ledgeway 2012) and the rich microvariation attested in the Modern Romance languages (Zanuttini 1997; Poletto 2000; Kayne 2000, 2005; Benincà \& Poletto 2004; Belletti 2008; D'Alessandro, Ledgeway \& Roberts 2010), the syntax of Medieval Romance remains under studied. Drawing on a new corpus of texts, the current article offers a comparative account of the key diachronic changes in clausal structure which take place within the medieval period and draws on the observed changes to shed new light on the passage from Latin to Medieval Romance, with a particular focus on the Verb Second (V2) property.

There are three main motivations for the study. Firstly, there is to date no comparative study on the evolution of Romance clausal structure WITHIN the medieval period, although diachronic studies on French alone are numerous. ${ }^{2}$ As the Medieval Romance languages have been claimed to be V2 (Benincà 1983-4 et seq.), the findings are particularly significant in offering a case-study of V2 change diachronically away from Germanic data which is better explored (cf. Walkden 2014). Secondly, although Salvi (2000, 2004, 2011) and Ledgeway (2012, 2015, in prep) are notable exceptions, diachronic studies concerning clausal structure which take into account both Latin and

\footnotetext{
1 This work is funded by the European Research Council Advanced Grant No. 269752 "Rethinking Comparative Syntax". I would like to thank Adam Ledgeway, Ian Roberts, Anders Holmberg, Theresa Biberauer, Jenneke van der Wal, Michelle Sheehan, David Willis and Christine Meklenborg Salvesen for feedback on earlier drafts of this work. Feedback from Joe Salmons and three anonymous Diachronica reviewers immeasurably improved the quality of this article. Needless to say, all errors remain my own.
}

2 On French see, in particular Skårup (1975), Adams (1987b), Vance (1993, 1995, 1997), Roberts (1993), Rouveret (2004) and Labelle \& Hirschbühler $(2005,2012)$. 
Early Romance data are lacking. I therefore set out to establish which factors condition the emergence of a V2 system diachronically. Thirdly, against the ongoing controversy as to whether the Medieval Romance languages were V2 or not (Benincà 2013 vs. Kaiser 2002), arguments have been invoked which highlight the the alleged 'implausibility' of a passage from the grammar(s) attested in Classical Latin texts to a V2 grammar in the medieval period (Rinke 2009:312; Sitaridou 2011:162). Considering whether these arguments are indeed implausible is therefore timely. The overall aim is to fill a lacuna in Romance scholarship and in our understanding of processes of diachronic change regarding core clausal structure and V2 more generally.

\subsection{The V2 Hypothesis}

The notion that the Medieval Romance languages were V2 systems is strongly associated with the work of Benincà $(1983-4,1995,2004,2006,2013)$, though the intuition that there are fundamental morphosyntactic differences between the medieval varieties and their modern counterparts is not new. ${ }^{3}$ The notion that the medieval languages uniformly licensed V-to-C movement, has subsequently been developed in a large number of data-rich studies of the syntax of Gallo-Romance (Adams 1987; Roberts 1993; Vance 1997; Labelle 2007; Vance, Donaldson \& Steiner 2009; Mathieu 2012; Steiner 2014), Ibero-Romance (Rivero 1986; Ribeiro 1995; Fernández Ordóñez 2009; Wolfe 2015c) and Italo-Romance varieties (Vanelli, Renzi \& Benincà 1986; Ledgeway 2009; Poletto 2014; Wolfe 2015b, 2015d, 2015f). ${ }^{4}$

Here I adopt the V2 hypothesis, but suggest that the V2 phenomenon within the medieval period is not homogeneous. Some of the clearest evidence in favour of the V2 hypothesis comes from clauses such as (1a-f) which feature 'Germanic inversion' where a subject unambiguously in a TP-internal position occurs after the finite verb, suggesting a location for the verb within the C-domain (Adams 1987b:4; Roberts 1993:56; Vance 1997:80; Salvesen \& Bech 2014:213; Poletto 2014:3-8):

(1) a. Non era euprisente per spiritu

NEG be.1SG.PST I present for spirit

'I wasn't present in spirit' (Sicilian, $D G 60$ )

b. $e$ così er' $=e^{\prime} \quad$ rivà $\quad$ a casa de Macho de Robin and so be.1SG.PST $=$ I arrive.PTCP at house of Macho de Robin 'and I thus arrived at the house of Macho de Robin' (Venetian, LM 22)

c...c'avia ego binkidu per rasone

\footnotetext{
${ }^{3}$ See Tobler (1875), Mussafia (1888) and Thurneysen (1892) in particular for ideas that in many ways foreshadow later comments on the V2 syntax of Medieval Romance.
} 
because-have.1SG.PST I win.PTCP for reason

'....because I had justly won' (Sardinian, $S M D B 2$ )

d. Ja vos=avoit $\underline{\text { il }}$ si longuement servi

already you=have.3SG.PST he so long serve.PTCP

'He has already served you such a long time' (French, Quête 119)

e. Acostumat avia li sanctade pagar a Dieu las horas

accustom.PTCP have.3SG.PST the saint to pay.INF to God the hours

'The Saint had become used to reciting her hours to God' (Occitan, Douceline 159)

f. et en faciendo estos seguramientos, ha él ya pensado

and in make.PROG these assurances have.3SG.PST he already think.PTCP

'And in making these assurances, he has already thought...' (Spanish, Lucanor 141)

A small body of work has sought to refute the V2 hypothesis for some or all of the languages, on the basis of attestation of V1 and V3* orders (Kaiser 2002:134; Rinke \& Elsig 2010:2563; Sitaridou 2012:577). ${ }^{5}$ Though the observation that the finite verb appears in second linear position with greater frequency in Modern Germanic than Medieval Romance clearly holds (Poletto 2013:161; Benincà 2013:68; Cognola 2013:Ch2), this is not to say that the Modern Germanic languages do not license V1 and V3* orders in a restricted subclass of clauses. ${ }^{6}$ These orders are particularly widespread in Early Germanic, where crucially BOTH a V2 syntax and widespread V1 and V3 orders are attested (Axel 2007:161-170, 200-227; Petrova 2012; Walkden 2014:§3.2-3.3, 2015). This diachronic analysis contributes to the debate, by showing that the nature of V1 and V3* orders licensed across Medieval Romance varies between languages and diachronic stages and is linked to ongoing changes concerning the V2 property.

\subsection{Textual Sources}

Data is presented from different diachronic stages of a range of Medieval Romance varieties. To minimise potential diachronic gaps in textual records, supplementary data for the very earliest periods (9th-11 th centuries) is drawn from both poetry and prose. ${ }^{7}$

The article also draws on a detailed reading of seven texts representing Sardinian, Sicilian, Venetian, Spanish, Occitan and French, for which 1000 clauses were analysed. All the texts, except

\footnotetext{
${ }^{5} \mathrm{~V} 3 *$ indicates orders where two or more constituents precede the finite verb.

6 See, for example, Westergaard (2009:20-24) for V3-triggering adverbs in Modern Norwegian, Haider (1982) on multiple fronted adverbials in Modern German and Frey (2004) on left-dislocation constructions in Modern German. Similar observations hold concerning V1 in joke-telling and Topic-drop constructions (see amongst others Huang 1984 and Önnerfors 1997).

${ }^{7}$ See recent discussion in Donaldson (2012:1033) who finds the poetry/prose distinction insignificant as regards the makeup of the left periphery in 10th-14th century French.
} 
Sardinian, considered separately, are used to investigate 'innovative' diachronic developments in the 13th and 14th centuries. ${ }^{8}$

\subsection{Background Assumptions}

I assume the left periphery of the clause to be made up of a set of hierarchically ordered projections (Rizzi 1997; Benincà \& Poletto 2004; Haegeman 2012), with the leftmost 'Frame' field associated with a scene-setting function, anchoring the speech act in terms of locative and temporal deixis and speech participants (Haegeman 2000:§5.5.1; Sigurðsson 2004; Giorgi 2010):

\section{(2) $[$ FrameP $[$ ForceP $[$ TopP $[$ FocP $[$ FinP $[$ TP... $]]]]]]$}

I follow a recent formulation of the V2 constraint in Holmberg (2015:§5) that '[t]he V2 property is made up of the two components....(a) A functional head in the left periphery attracts the finite verb (b) This functional head wants a constituent moved to its specifier position' (Holmberg 2015:§5). ${ }^{9}$ This is interpreted as a feature triggering verb movement and an Edge Feature (EF) which triggers the merger of a null or overt phrasal constituent in the left periphery. Following Poletto (2002, 2013), Roberts (2010, 2012) and Biberauer \& Roberts (2015) I suggest that the locus of the V2 property may vary between languages and that, minimally, this variation concerns the ability for either Fin alone (3a) or Force and Fin (3b) to be the locus of the V2 property: 1011
(3) a. [FrameP [ForceP $[$ TopP [FocP $\left.\left.\left.\left.\left[\mathrm{FinP} \mathbf{X P}\left[\mathrm{Fin}^{\circ} \mathbf{V}\right][\mathrm{TP} . .].\right]\right]\right]\right]\right]$
b. [FrameP $\left[\right.$ ForceP XP $\left[\right.$ Force $\left.^{\circ} \mathbf{V}\right] \ldots\left[\right.$ FinP XP Fin ${ }^{\circ} \vee[$ тр...]]]]]]

For our purposes the observation is that in Fin V2 systems we predict null and overt constituents to be able to occur in the Frame (Scene-Setters, Hanging Topics, Speaker-Oriented Adverbials), Force, Topic and Focus fields and nothing A PRIORI rules out a successive set of these projections hosting overt constituents simultaneously. The result would be a 'relaxed' V2 system with widespread verbthird, -fourth or -fifth. On the other hand, Force-V2 systems like (3b) have a more restricted left

\footnotetext{
${ }^{8}$ Note that legal texts were used for the analysis of Old Sardinian and Later Old Venetian due to gaps in the textual records which prevent the use of religious prose (cf. Bentley 1999:324-325 for discussion of the Sardinian textual records and Stussi 1965:Ch.1 for Venetian).

${ }^{9}$ See also Haegeman $(1996: 143,2012: 108)$ and Cardinaletti \& Roberts (2002:153) for similar formulations.

10 This is therefore analogous to the varying targets of finite verb movement within the T- $v$-V domain of the clause in SVO languages (Pollock 1989; Belletti 1990; Ledgeway \& Lombardi 2005).

${ }^{11}$ I follow Poletto (2002) in (3b) in assuming that Force-V2 languages feature a 'double bottleneck' where the verb and merged XP reach Force ${ }^{\circ}$ and Spec-ForceP via Fin ${ }^{\circ}$ and Spec-FinP (pace Biberauer \& Roberts 2015).
} 
periphery where only a constituent in the Frame field can precede the constituent satisfying V2. Verb-third is therefore not ruled out, but orders where four or more constituents precede the finite verb, however, are. In this article I make a further novel claim that the types of null elements occurring in the left periphery are also sensitive to this Fin/Force V2 distinction, accounting for the rich variation we find as regards V1 orders in Medieval Romance synchronically (Wolfe 2015d) and diachronically.

Finally, I assume as background to the analysis, following in particular Ledgeway (2012:270), that (conservative) Classical Latin featured a form of SOV grammar with the verb remaining in-situ within the $v$-VP-complex and OV orders derived via 'roll-up' movement from the VP-complement position to its specifier (Kayne 1994):

Figure 1.

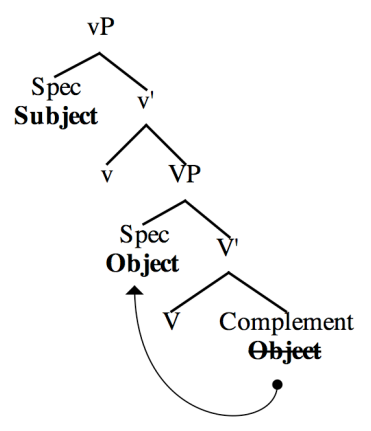

This point is significant as I argue below that a reanalysis of this rollup movement was in fact a crucial precursor to the emergence of Medieval Romance's V2 syntax

\subsection{Outline}

Section 2 and 3 present descriptive overviews of key points of continuity and variation concerning the V2 syntax of Early and Late Medieval Romance. Section 4 argues that the data can best be accounted for by assuming an early Fin-V2 system in Early Medieval Romance (EMR), reanalysed as Force-V2 in certain varieties. Section 5 argues that Old Sardinian has the most 'conservative' syntax as a Fin-VSO system inherited from late Latin.

\section{EARLY MEDIEVAL ROMANCE}

There exists no syntactic study of the very earliest Romance dialectal sources, in part due to the non-trivial philological concerns arising when testing the chronology and reliability of certain 
available texts. ${ }^{12}$ Nevertheless, a close reading of the textual evidence leads to the conclusion that across the EMR textual record (from the 10th to 12th centuries), the varieties are uniform in certain key respects. ${ }^{13}$

Consider Information Focus, which following Cruschina (2006) is understood as encoding 'brand new/unanchored' non-contrastive information. As the data show, ${ }^{14}$ informationally new constituents are licensed alongside Topics in the CP in EMR, in contrast to Modern Romance where discoursenew information is standardly realised in postverbal position (Belletti 2001:63; Cruschina \& Ledgeway in press:§31.2), with the exception of Modern Sardinian and Sicilian (Cruschina 2006:371f; Bentley 2007:52f; Mensching \& Remberger 2010:§2.2):1516

(4) Plein est defigure é signefiance

clear be.3SG of figure and meaning

'This is clear with respect to form and meaning' (French, QLR I, 4, c.1170)

(5) El boscal d'Aimertal Pas donero Matfres Bec e sos fraire

the thicket-wood of Aimert al Pas give.PST.3PL Matfre Bec and his brother

ellor maire

and $=$ their mother

'Matfre Bec, his brother and their mother donated the thicket wood of Aimert al

Pas' (Occitan, Chartes, 20, 1120)

(6) Grandes signos contieron, quand est'infant naçió

great signs take-place.3PL.PST when this child be-born.3SG.PST

'When this child was born, great wonders took place'(Spanish, Alexandre 136, 1178-1250)

(7) fiios de ankilla de juigi sunt

children of slave of iudice be.3PL

'They are children of a slave of the iudice' (Sardinian, SMDB 25, 1120-1146)

(8) Un eisemple direm d'un bon hom qui ot tres amis

an example tell.1PL of-a good man that have.3SG.PST three friends

\footnotetext{
12 See Wright (1991) for discussion of these problems, alongside Vincent (2014) for Italo-Romance.

${ }^{13}$ Verse can of course influence syntax (see Somers \& Dubenion-Smith for a recent Germanic case-study), yet the lack of lengthy prose texts from Early Old Spanish entailed the use of two verse texts: Mio Cid and Libro de Alexandre. The core observation for the present analysis is that these texts pattern precisely with the other EMR prose texts considered with regard to the factors relevant for the present paper.

${ }^{14}$ I exclude here for EMR Sicilian and Venetian due to the scarcity of texts from the 12th century.

15 Issues concerning the dates of composition of the texts cited are not simple, with approximate dates have given with all examples. See Parry (1998:94-95) and Delfuoco (2005) on the Sermoni Subalpini, Menéndez Pidal (1926), Smith (1972:xxxiv) and Duggan (1989:12-15) on Mio Cid, Bleiberg, Ihrie \& Pérez (1993:41) on the Libro de Alexandre, Merci (1978) and Virdis (2004) for the Carta Arborense and the MCVF corpus for French texts.

${ }^{16}$ Constituents in the examples that follow were tagged as discourse-old if they occurred in the previous ten lines of a particular section of text.
} 
'We now discuss an example of a good man who had three friends' (Piedmontese, Sermoni, f.146 r., 12th C)

Information Focus is frequently found following a Topic (9), which itself can be preceded by a Frame-Setter (10) (Benincà 1995:329; Ledgeway 2007:124, 2008:440; Salvi 2012:105; Poletto 2014:16):

(9) a. E[ Tорр pur çó que cist lignages numéément dout si le servise Deu celebrer, since that these lineages named should thus the service God celebrate.INF

$$
\begin{gathered}
\text { [FocP besuinz [FinP...fud } \\
\text { necessary be.3SG.PST the... ke }
\end{gathered}
$$

'Since these lineages had to therefore celebrate the service of God, it was necessary that...' (French, QLR I, 1, c. 1170)

b. E [TopP sobre tot aizo [FocP per amor de Deu e de sant Antoní [FinP... donam and above all this for love of Lord and of Saint Anthony give.1PL segur a totz aquels omes et totas las femenas....

insurance to all those men and all the women

'And in addition to this, for our love of the Lord and Saint Anthony, we insure all those men and women....' (Occitan, Chartes, 41, 1143)

(10) a. [FrameP $\operatorname{Or}$ [TopP Caim [FocP del so lavor [FinP...ofria a Deu de les plus croe now Cain from his work offer.3SG.PST to God of the most worst gerbes que el avea]]]

sheaves that he have.3SG.PST

'Cain now offered to God the worst sheaves [of grain] that he had from his work' (Piedmontese, Sermoni, f. 128v, 13th C)

b. [FrameP Si nos d'aquí non imos [TopP en paz] [FocP nunca [FinP... bivremos]]]] if we from=here NEG go.1PL in peace never live.1PL 'If we don't leave here, we'll never live in peace' (Spanish, Alexandre 254, 1178-1250)

Significantly, the Placiti Cassinesi, possibly the earliest written texts in Italo-Romance, show a Topic + Focus order in a complement clause (11) (Ledgeway 2011:216). See also an analogous order from the earliest Sardinian text (Merci 1978) (12):

(11) Sao ko [Topp kelle terre per kelle fini, que, ki, contene, [Focp trenta anni know.1SG that those lands for those confines that here contain.3SG thirty years [FinP... le possette parte sancti Benedicti]]] them $=$ possess.3SG.PST part saint.OBL Benedict.OBL

'I know that those lands, within those borders which are contained here, have belonged to the part of the monastery of St Benedict for thirty years' (Placito 1, Ledgeway 2011:215, 960AD)

(12) [Topp Ego iudice Torbini de Lacon, [FocP potestando parte de Arbarea cun donna Ana I iudice Torbini de Lacon govern.PROG part of Arborea with donna Ana de Zori e regina coiube mmia [FinP... facemus ista carta a Gostantine d'Orrubu fratile of Zori and queen consort my make.1PL this carta to Gostantine d'Orrubu brother meu ed amabile meu]]] 
brother and friend my

'I Iudice Toribini de Lacon, governing part of Arborea with by wife and queen consort Ana de Zori, make this recording [of a donation] to Gostantine d'Orrubu, my brother and friend' (Sardinian, CA, Merci 1978:370, c.1100).

Consider the particle SI. Despite a huge literature, there is to date no uniform analysis of either its functional distribution or its correct formal characterisation. ${ }^{17}$ Following the spirit of the analysis in Adams (1987b:9), Poletto (2005), Ledgeway (2008) and Salvesen (2013:143) we can view SI as a quasi-expletive element, which satisfies Fin's EF when no null or overt constituent is able to. SI in EMR can be preceded by multiple constituents lexicalising the Frame-Topic-Focus field:

(13) Durement en halt si recleimet sa culpe strongly on high SI confess.3SG his sin 'He confesses his sins aloud' (French, Roland 2014, Marchello-Nizia 1985:158, 1040-1115)

The Strasbourg Oaths, commonly considered the first written texts in 'Romance' (Ewert 1934:22-30; Ayres-Bennett 1995:16-30; Pountain 2011:615-617), ${ }^{18}$ show clear evidence of a low position for SI within the left periphery (14):

[FrameP $d$ 'ist di in avant, [TopP in quant Deus savir et podir me dunat, [FinP... from-this day in forward in sofar-as God knowledge and power me give.3SG

si salvarai eo cist meon fradre Karlo...]]]

SI support.1SG.FUT I this my brother Charles

'from this day forward, insofar as God gives me knowledge and power, I will support this my brother Charles...' (Strasbourg Oaths, Price 1971:8, 9th-10thC)

Across all varieties except Sardinian (cf. §5), V1 orders fall into three discourse-marked categories. Firstly we find Narrative V1, with a discourse-initial verbum dicendi as in Germanic (Sigurðsson 1990:46; Önnerfors 1997; Axel 2007:215; Petrova 2011:212):
a. Respont
lo reis: Faites
l'ome vener!

respond.3SG.PST the king make.2SG.IMP the-man come.INF

'The King responded: 'make the man come!' (Piedmontese, Sermoni, f.133r, 12thC)

b. Respundi Samuel: 'cument?... respond.3SG.PST Samuel: 'how?'

'Samuel responded: 'how?' (French, QLR I, 56, 1170)
c. dis
Jaufre: mut as
ben parlat

say.3sg.pst Jaufre very have.2SG well speak.PTCP

'Jaufre said: you have spoken very well' (Occitan, Jaufré 2896, Jensen 1990:537, c.1200)

d. Ffablo

mio Çid bien e tan mesurado

17 For the distribution of SI across Medieval Romance, see Fleischman (1991) Van Reenen \& Schøsler (2000), Salvi (2002)and Ledgeway (2008). 
speak.3SG.PST my Cid well and so restrained

'My Cid spoke well and in a restrained fashion...' (Spanish, Cid, 7, 3, c.1200)

A second category concerns Topic Continuity V1, with an initial Null Topic co-referential with a preceding nominal expression (see Santorini 1989:55 and Sigurðsson 1990:62 on Germanic parallels):

(16) a. Ané a sun premer amì, qui era munt rich go.3SG.PST to his first friend who be.3SG.PST very rich

'[He] went to his first friend, who was very rich' (Piedmontese, Sermoni, f. 146 r, 12thC)

b. Vint en Bethléém

come.3SG.PST in Bethlehem

'[He] came to Bethlehem' (French, QLR I, 58, 1170)
c. Laiset
tot lo quart del
blat que avia
a Solpiac

leave.3SG.PST all the section of-the land that have.3SG.PST at Solpiac

'[She] left all the portion of the land that she had at Solpiac' (Occitan, Chartes 92, 1160)

d. Tiene dos arcas lennas de oro esmerado

has.3SG two chests full of gold fine

'[He] has two chests full of finest gold' (Spanish, Cid 5, 113, 3 c.1200)

A third category occurs in rhematic clauses, which serve 'to introduce not-yet activated referents into a discourse' (Lambrecht 1994:143). Parallel V1 rhematic clauses are especially common in the earlier stages of the Germanic languages (Axel 2007:120f; Petrova \& Solf 2008:331; Petrova 2011:213):

(17) a. Ven lo seten iorn

come.3SG.PST the seventh day

'The seventh day came' (Piedmontese, Sermoni, f.158r, 12thC)

b. Aparceurent sei quel'arche fud venue en l'ost appear.3PL.PST as-if that the-arch be.3SG.PST come.PTCP on the-host

'It appeared as if the arch was above the host' (French, QLR I, 14, 1170)

c. arss Deus cell lin

burn.3SG.PST God that lineage

'God burnt that lineage' (Occitan, Sainte Foi 589, Jensen 1990:535, 1054-1076)

d. Gradeçiolo don Martino e reçibio...

thank.3SG.PST=him Don Martino and receive.3SG.PST

'Don Martino thanked him and received...' (Spanish, Cid, 199, 8, c.1200)

One can thus identify points of syntactic continuity within EMR texts, which are linked below to a common Fin-V2 grammar, which is descriptively 'relaxed'.

\section{LATE Medieval Romance}


The syntactic homogeneity attested in the earliest Romance textual records does not persist into the later period. ${ }^{19}$

\subsection{Later Old Sicilian and Occitan}

Our Sicilian text dates from the first half of the 14th century and our Occitan text from the 13th century, yet the V2 system attested in these texts patterns exactly with EMR as regards the V2 syntax.

Both texts show evidence of CP-Information Focus (see Cruschina 2011:122 on Old Sicilian and Benincà 2004:268 on Occitan):

(18) a.e cum sancta Maria eranu autri sanctifimini vistuti diblancu and with Saint Maria be.3PL.PST other saint women dressed of white 'and other women saints dressed in white were with Saint Maria.' (Sicilian, SG 158, 1301-1350)

b. Mortification de carn comenset a penre tantost mortification of flesh begin.3SG.PST to take.INF early

'She began to flagellate herself early [in the morning' (Occitan, Douceline 48, 13th C)

There is clear evidence that a Frame-Setter and/or Topic and Focus can co-occur in the clausal left periphery within both texts (see Scremin 1986:46f and Benincà 2013:17 on Sicilian and Vance, Donaldson \& Steiner 2009 and Sitaridou 2012:572 on Occitan). This was identified above as being found in EMR and accounts for the robust attestation of V4* orders (Table 1):20

(19) a. [FrameP tamen poy di la morti loru], [TopP li ossa loru] [FocP pir virtuti divina [FinP... then after of the death their the bones their by virtue divine operannu miraculi]]]] perform.3PL miracles 'Then after their death, their bones perform miracles through divine virtue' (Sicilian, $S G$ 262, 1301-1350)

b. [TopP Illi, [FocP per amor del Senhor, [FinP... lur=lavava los pes]]] she for love of-the Lord them=wash.3SG.PST the feet 'Through her love of the Lord, she washed their feet' (Occitan, Douceline 45, 13th C)

\footnotetext{
19 The term Late Medieval Romance is used as shorthand to refer to the 13th and 14th centuries.

20 The low, albeit licit, occurrence of V5* orders in Table 1 would simply be the result of it being uncommon that five or more left-peripheral elements co-occur in the languages.
} 
Table 1. Verb Placement in Later Old Occitan and Old Sicilian Matrix Clauses

\begin{tabular}{ccccc} 
& \multicolumn{2}{c}{ Old Occitan } & \multicolumn{2}{c}{ Old Sicilian } \\
\hline V1 & N & $\%$ & $\mathrm{~N}$ & $\%$ \\
V2 & 38 & $7.52 \%$ & 52 & $5.21 \%$ \\
V3 & 188 & $53.29 \%$ & 318 & $50.24 \%$ \\
V4 & 50 & $29.47 \%$ & 189 & $29.86 \%$ \\
V5 & 8 & $7.84 \%$ & 61 & $9.64 \%$ \\
V6 & 4 & $1.25 \%$ & 11 & $1.74 \%$ \\
V7 & 0 & $0.63 \%$ & 1 & $0.16 \%$ \\
Total & 638 & $0.00 \%$ & 1 & $0.16 \%$ \\
\hline
\end{tabular}

The particle SI within the Sicilian text occurs following multiple constituents within the FrameTopic-Focus field:

(20) [TopP killi pirsuni [FocP pir la grandi pagura ki àppiru] [FinP... si partèru ]]] those people for the great fear that have.3PL.PST SI leave.3PL.PST

'Those people left because of the great fear that they felt' (Sicilian, SG 262, 1301-1350)

Finally, witness the examples below, showing instantiations of the tripartite typology of V1 structures found in the EMR texts (see Sitaridou 2005:366-369, 2012:571 on Occitan, Benincà 2004:271 on Sicilian). Topic Continuity V1 (21) and Rhematic V1 (22) are found within both texts, though Narrative V1 is present in Sicilian only (23):

(21) a. Tornau al monisterio return.3SG.PST to-the monastery ' $[\mathrm{He}]$ returned to the monastery' (SG 86, 1301-1350)
b. Amava e queria luechs solitaris

love.3SG.PST and want.3SG.PST places solitary

'She loved and wanted places where she could be alone...' (Occitan, Douceline 107, 13th C)

(22) a. Passau lu sicundue lu terzu iornu pass.3SG.PST the second and the third day

'The second and third day went by' (SG 256, 1301-1350)

b. Estavan totas plenas de gauch e de meravilla be.3PL.PST all full of joy and of marvel 'They were all full of joy and wonderment' (Occitan, Douceline 107, 13th C)

(23) Dichi, adunca, sanctu Gregoriu ki... say.3SG.PST then Saint Gregory that 'Saint Gregory said again that..' (Sicilian, SG 254, 1301-1350) 
The evidence for the V2 system instantiated in 14th century Sicilian and 13th century Occitan is striking in the extent to which it patterns with EMR as regards the properties discussed.

\subsection{Later Old French, Spanish and Venetian}

In contrast to the other varieties discussed, there is a large literature on Old French which demonstrates that the V2 system changes fundamentally in the passage from the 12th to the 13th century (Rouveret 2004; Labelle 2007; Donaldson 2012; Simonenko \& Hirschbühler 2012; Steiner 2014; Labelle \& Hirschbüler in press). Although there is no DIACHRONIC literature on Venetian V2 (cf. Benincà 1983 for synchronic discussion), and little diachronic literature on Spanish (Fontana 1993; Wolfe 2015b), I suggest here that both underwent similar changes to French in the 13th and 14th centuries, such that the V2 systems differ markedly from Later Old Sicilian and Occitan and EMR.

Firstly, no hallmarks of CP-Information Focus position are found within the text. Note that extended Venetian texts prior to the 13th century are lacking, though it was shown above that a 12th century Northern Italian Dialect, Piedmontese, shows clear evidence of CP-Information Focus, providing indirect evidence that Venetian may have previously licensed left-peripheral Information Focus. This is no longer licensed in the texts, rather all examples of fronted direct objects, for example, are discourse-old (see Marchello-Nizia 1995:99f; Vance 1997:57; Labelle \& Hirschbühler 2012:20; Zimmerman 2014:141 on French and Wolfe 2015b:139-140 on Spanish):2122

(24) a. Cele semblance dont l'evangile parole poons nos veoir... that figure of-which the-gospel speak.3SG.PST can.1PL we see.INF

'We can see that figure about which the gospel speaks....' (French, Quête 128, 1215-1230)

b. et eso mismo fizo a las arcas... and that same do.3sG to the chests...

'and he did the same thing to the chests...' (Spanish, Lucanor 204, 1335)

c. (E) co dis=el plusorfiade and this say.3SG.PST $=$ he often

'And he said this often' (Venetian, Lio Mazor 19, 1312-1314)

Secondly, V3 is heavily restricted. In contrast to the other varieties considered, there are no Topic + Focus orders, a fact which accounts for the near-total absence of V4* in Table 2:

\footnotetext{
${ }^{21}$ Note that this is a different finding to the proposal put forward in Benincà $(2004,2006)$, where Old Venetian is included as a language which licenses CP-Information Focus.

${ }^{22}$ Crucially these direct objects still occur with no resumptive clitic, which is yet another piece of evidence for a V2 analysis (cf. Beninca 2004 in particular for discussion).
} 
Table 2. Verb Placement in Later Old French, Spanish and Venetian Matrix Clauses

\begin{tabular}{|c|c|c|c|c|c|c|}
\hline & \multicolumn{2}{|c|}{ Old French } & \multicolumn{2}{|c|}{ Old Spanish } & \multicolumn{2}{|c|}{ Old Venetian } \\
\hline & $\mathrm{N}$ & $\%$ & $\mathrm{~N}$ & $\%$ & $\mathrm{~N}$ & $\%$ \\
\hline V1 & 0 & $0.00 \%$ & 11 & $2.29 \%$ & 154 & $24.37 \%$ \\
\hline $\mathrm{V} 2$ & 475 & $75.16 \%$ & 436 & $90.83 \%$ & 371 & $58.70 \%$ \\
\hline V3 & 155 & $24.53 \%$ & 32 & $6.67 \%$ & 103 & $16.30 \%$ \\
\hline V4 & 2 & $0.32 \%$ & 1 & $0.21 \%$ & 4 & $0.63 \%$ \\
\hline V5 & 0 & $0.00 \%$ & 0 & $0.00 \%$ & 0 & $0.00 \%$ \\
\hline V6 & 0 & $0.00 \%$ & 0 & $0.00 \%$ & 0 & $0.00 \%$ \\
\hline V7 & 0 & $0.00 \%$ & 0 & $0.00 \%$ & 0 & $0.00 \%$ \\
\hline Total & 632 & $100 \%$ & 480 & $100 \%$ & 632 & $100 \%$ \\
\hline
\end{tabular}

V3 is instead restricted to a small class of initial-Frame-Setters (25), Hanging Topics (26) and speaker-oriented adverbs (27) (see on French Foulet 1928:311; Skårup 1975:435-459; Jensen 1990:539-540; Roberts 1993:144; Vance 1995:183, 1997:61-62, on Spanish Fontana 1993:111, Benincà 2004:279 and Wolfe 2015b):

(25) a. Et quant il est apareilliez, il prent ses armes et monte and when he be.3SG appear.PTCP he take.3SG his weapons and ride.3SG.PST

'When he appeared, he took his weapons and rode...' (French, Quête 129, 1215-1230)

b. Et luego que llego a la puerta el diablo abrioge=la And soon that arrive.3SG.PST at the door the devil open.3SG.PST=it

'And as soon as he arrived at the door, the devil opened it' (Spanish, Lucanor 204, 1335)

c. Unde Brat levà la $m a(n)$

thus Brat raise.3SG.PST the hand

'Brat then raised his hand' (Venetian, Lio Mazor 51, 1312-1314)

(26) Li chevalier qui sont en pechié mortel, ce sont li terrien... the knights that be.3PL in sin mortal they be.3PL the earthly... 'the knights who are mortal sinners, they are the earthly ones' (Quête 143, 1215-1230)

(27) a. Et neporec Nostre Sires avoit mis tant de bien en toi... and nevertheless our Lord has.3SG.PST put.PTCP such of good in you 'And nevertheless our Lord has put so much good in you...' (French, Quête 126, 1215-1230)

b. Cierta mente este omne non es culpado certain ADV this man NEG be.3SG guilty

'Certainly, this man is not guilty' (Spanish, Lucanor, 205, 1335)

Thirdly, in contrast to Early Old Gallo-Romance and 14th century Sicilian, all 145 cases of matrix SI in the Old French text either feature SI as the sole preverbal constituent (28a) or show SI preceded 
by a Hanging Topic or Frame-Setter (28b), of the types that permit V3 when co-occurring with a fronted Topic as in (25a, 26a, 27a). We do not find cases where a non-clitic-doubled Topic precedes SI, which are widespread in Early Old French and 14th century Sicilian (13, 14, 20) :

(28) a. Si lace son hiaume

SI fasten.3SG his helmet

'He fastened his helmet' (French, Quête 132, 1215-1230)
b. Quant il a
ce dit,
si se $=$ redrece
en estant

when he have.3SG that say.PTCP SI REFL=get-up.3SG in standing

'When he had said this, he got up' (Quête 132, 1215-1230)

Finally, in contrast to all the other varieties considered, there are no V1 matrix declaratives in the Old French text (see Table 2, Skårup 1975:291; Vance 1997:18-20; Rouveret 2004:193-195). In the Spanish text, V1 is found but accounts for a mere $2.29 \%$ of matrix clauses showing Narrative V1:

(29) Fablava otra vez el conde Lucanor con Patronio [su consejero] Speak.3SG.PST other time the count Lucanor with Patronio his adviser 'Count Lucanor spoke another time with Patronio, his adviser' (Spanish, Lucanor 172, 1335)

There is a clear quantitative difference between the Venetian text and its Spanish and French counterparts, as matrix V1 structures are widespread (24.37\%). The majority (142/154) occur, however, with a verbum dicendi and are thus cases of Narrative V1 (38), or occur with an initial negator $(9 / 142)$ :

(30) dis che si

say.3SG.PST that yes

'He said yes' (Venetian, Lio Mazor 60, 1312-1314)

The remainder (3/154) show a construction not found in the other Later Medieval Romance texts, where V1 is found with a topical antecedent that has a very high degree of discourse salience and is anchored in the 'here and now', mirroring a similar construction in the Modern Germanic languages, characteristic of direct speech (Sigurðsson 1989:145f; Önnerfors 1997; Sigurðsson \& Maling 2010:60f):

(31) ela... la quala dis... " "çeto che viti che Maria...»

she the which say.3SG.PST accept.1SG that see.1SG.PST that Maria...

'she, who said 'I accept that I saw that Maria...' (Venetian, Lio Mazor 47, 1312-1314)

Crucially, we find no cases of Rhematic V1 or Topic Continuity V1, widespread across EMR and maintained in Later Old Occitan and Sicilian. 
The key descriptive generalisation can be framed simply. EMR shows homogeneity as regards V2.

Within the 13th and 14th centuries, however, a split emerges between systems that maintain the EMR V2 system (Sicilian, Occitan) and those which innovate a stricter V2 (French, Spanish, Venetian):

Table 3. The V2 System in Medieval Romance

\begin{tabular}{rcccccc}
\hline & Topic & Rhematic & Narrative & Deictic & CP & Top + \\
& Continuity & V1 & V1 & Topic & Information Foc (+SI) \\
& V1 & & & V1 & Focus & \\
Early Old French & + & + & + & N/A & + & + \\
Early Old Occitan & + & + & + & N/A & + & + \\
Early Old Piedmontese & + & + & + & N/A & + & + \\
Early Old Spanish & + & + & + & N/A & + & + \\
Later Old Sicilian & + & + & + & N/A & + & + \\
Later Old Occitan & + & + & - & N/A & + & + \\
Later Old French & - & - & - & - & - & - \\
Later Old Spanish & - & - & + & - & - & - \\
Later Old Venetian & - & - & + & + & - & - \\
\hline
\end{tabular}

\section{From Early to Late Medieval Romance}

\subsection{The Original Fin-V2 System}

The descriptive generalisations outlined above for EMR can be captured by assuming that in the languages in question the locus of the V2 syntax was a low C-head, Fin. ${ }^{23}$ This type of V2 system is maintained in Later Old Occitan and Sicilian and yields a descriptively 'relaxed V2' grammar.

Considering first the EMR data in (4-8) and the Later Old Sicilian and Occitan data (18), this hypothesis accounts for the occurrence of Information Focus in the prefield, as informationally 'new' elements are standardly assumed to occupy one of the lowest functional projections within the C-layer (Benincà \& Poletto 2004:71; Cruschina 2012:18). Consider (4) which would have the

\footnotetext{
${ }^{23}$ See Vanelli, Renzi \& Benincà (1986:53) and Vance, Donaldson \& Steiner (2009) for the intuition that 13th century Occitan constitutes a 'relaxed' V2 system and Benincà $(2004,2006,2013)$ and Ledgeway (2007, 2008) for the notion that the locus of V2 in Old Italo-Romance varieties was a low-head in the left periphery. Rouveret (2004) and Labelle (2007) present accounts of Old French syntax, in which an earlier grammar with low V2 changes to a grammar where a high head is the locus of V2 (explicitly Force in Rouveret's 2004:220 account).
} 
following structure, with the verb moving to Fin and the fronted Focus satisfying Fin's V2-related EF:

(32) [FrameP [ForceP [TopP [FocP Plein [FinP plein [Fin ${ }^{\circ}$ est $]$ [TP... est plein de figure é signefiance ]]]]]]

Looking at (32), note the prediction made above for Fin-V2 systems that multiple constituents in the Frame-Force-Topic field can precede the Focus (as clearly attested in EMR 9-12). A quantitative assessment is possible in Later Old Sicilian and Occitan, as V4* orders are robustly attested (11.7\%/ $9.27 \%$ of matrix clauses) as a reflex of the co-occurrence of Frame-Setters, Topics and Foci in CP.

Turning to V1, I propose following Benincà (2004:290, 2006:69) and Poletto (2014:21-23) that the Topic Continuity V1 and Rhematic V1 structures feature a variant of the null pronoun pro found in Null Subject Languages (Holmberg 2005; Roberts 2010; Sheehan 2016). In Fin-V2 systems, assume that the the Topic-field can host this variant of pro, proTop, which moves to the Topic-layer via SpecFinP and thus satisfies the V2 constraint on Fin. For Narrative V1, I follow Reis (1995) that these clauses are recounted rather than directly asserted and suggest, following Zwart's (1997:220), that these feature a null discourse operator in Spec-ForceP which types the clause as $\{$-ASSERTED\}.

The long-held intuition that V1 structures in EMR and some of the Later Medieval Romance varieties are widespread (Ledgeway 2008:442; Salvi 2012:106-7; Sitaridou 2012:570; Labelle \& Hirschbühler 2012:§4; Hansch 2014:227-239), is therefore captured in terms of alternative strategies to satisfy the V2 constraint through merger of a null element in the left periphery, yielding surface V1 (see also Fontana 1993:100-110), or merger of an overt constituent, resulting in surface $\mathrm{V} 2 *$.

Finally, consider SI in Early Gallo-Romance and Later Old Sicilian. As a form of 'last-resort' strategy to satisfy the V2 constraint on Fin, its distribution matches that of all other merged constituents satisfying V2, as SI follows constituents within the Frame-Topic-Focus layer (akin to the case-study above with a Focus which satisfies Fin's EF):24

(33) ...[TopP killi pirsuni [FocP pir la grandi pagura ki àppiru] [FinP si [Fin ${ }^{\circ}$ partèru $\left.\left.\left.] \ldots\right]\right]\right]$

The characteristics of EMR and Later Old Occitan and Sicilian V2 can thus be accounted for under a Fin-V2 analysis.

\footnotetext{
${ }^{24}$ See Ledgeway (2008) who also locates SI within FinP in 14th century Old Neapolitan, which he analyses as a Fin-V2 language. Note, however, that for Ledgeway SI is a head, a proposal I do not adopt here in line with Benincà (2004, 2006), Salvesen (2013) and Poletto (2014). See also Marchello-Nizia (1985:158) for a number of cases amenable to an analysis as [INFORMATION FOCUS + SI] strings, which she notes as typical of the oldest French texts.
} 


\subsection{The Reanalysis to Force-V2}

As noted above, there are fundamental syntactic differences between V2 in Later Old French, Spanish and Venetian and EMR. I propose to account for these differences in terms of a reanalysis from an earlier Fin-V2 system to an innovative Force-V2 system, triggered by the loss of CPInformation Focus.

Early Old French licensed CP-Information Focus (Labelle 2007:302-305; Labelle \& Hirschbühler 2012:15, 19-21; Mathieu 2012:341), whereas clear evidence of this in La Quête and 13th century French in general is lacking (Marchello-Nizia 1995:99f; Vance 1997:57; Zimmerman 2014:14). The secondary literature on Old Spanish is less extensive, though note that Fernández Ordóñez (2009:13-15) and Sitaridou (2011:176) suggest that the Alfonsine Prose from the 13th century shows clear cases of left-peripheral Information Focus in texts dating only fifty years prior to Conde Lucanor, where it is not licensed. ${ }^{25}$ Plotting clear diachronic progression in Old Venetian is challenging due to the absence of extended texts in the 13th century. The 12th century Piedmontese data presented in $\$ 3.1$ may however be an indirect indication that Northern Italian Dialects originally licensed CP-Information Focus.

I therefore proceed with the hypothesis that the loss of CP-Information Focus represented an innovation.

Once the bi-partite Fin/Force V2 typology (Roberts 2012; Biberauer \& Roberts 2015) is adopted, a question arises concerning how language-acquirers differentiate between the input of a Fin and Force-V2 grammar. The string [INFORMATION FOCUS $V_{\text {Fin }}$ ] may be crucial here as the locus of Information Focus as the lowest discourse-related functional projection in the left periphery provides an unambiguous cue that the grammar cannot feature verb-movement to a projection higher than Focus. ${ }^{26}$

Once Information Focus is no longer licensed in CP, but post-verbally as in Modern Standard French (Lambrecht 1994:22; Belletti 2005), Spanish (Zubizarreta 1998:Ch3) and Venetian, ${ }^{27}$

${ }^{25}$ Fernández Ordóñez (2009:28-29) suggests there is dialectal variation as regards CP-Information Focus in 13th century Spanish. This may partly map onto variation in modern peninsular Spanish varieties (JiménezFernández 2015), a possibility I leave to future research to explore.

${ }^{26}$ See also Poletto (2014:61-63) who links the loss of Information Focus to the loss of V2 in Old Italian. My argumentation here is somewhat different, linking its loss to the loss of Fin-V2, but not V2 per se.

${ }^{27}$ This is not a claim that Spanish, French and Venetian are wholly homogeneous as regards the realisation of postverbal Focus, simply that they share the property of Information Focus being realised postverbally (cf. Belletti 2005). 
acquirers will no longer receive the [INFORMATION FOCUS $\mathrm{V}_{\text {Fin] }}$ cue and V3* will also be affected, as [TOPIC + INFORMATION FOCUS $\mathrm{V}_{\text {Fin }}$ ] orders, uniformly licensed in EMR, will not feature in the innovative grammar. This is directly attested in Later Old French, Spanish and Venetian.

Let us hypothesise that given these considerations, the child reconstructs an 'innovative' Force-V2 grammar of the type outlined in 1.4 above. Spec-ForceP must therefore attract a Topic or (Contrastive) Focus from the Topic-Focus layer to satisfy its Edge Feature. It is this change from a Fin-V2 to a Force-V2 grammar that appears to characterise many of the Germanic languages (see Walkden 2015).

This predicts the restrictions on V3 and the absence of V4* noted above in the 'innovative' texts. The Force-V2 account predicts that only one constituent occupying the highest Frame-layer of the $\mathrm{CP}$ will be able to precede the moved constituent, standardly a Topic, in Spec-ForceP:

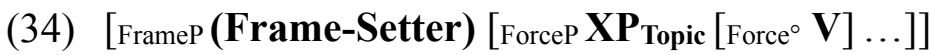

Considering the Later Old Spanish, French and Venetian data on V3, note that it is indeed restricted to initial wh-, adverbial and temporal clauses along with scene-setting adverbs standardly analysed as occupying the Frame-field (Poletto 2000:100; Benincà \& Poletto 2004:66; Öhl 2010:62). Speaker-oriented adverbials also occur in V3 configurations. Again hypothesise in line with similar proposals by Haumann $(2007: 277)$ that these V3 adverbs also occupy the Frame-field. ${ }^{28}$ Furthermore, note the initial Hanging Topic (24a), an element again analysed as preceding the Topic-Focus layer (Frascarelli 2000:169; Ledgeway 2010:279) and shown by Poletto (2002:235) to occupy a structurally higher position than ForceP. The nature of V3 in the 'innovative' texts therefore supports the notion of a novel Force-V2 grammar where V3-triggering elements can only occur in the Frame field.

Recall that (non-negated) V1 is restricted to Narrative V1 in Later Old Spanish and Venetian alongside a deictically-anchored Null Topic structure in Later Old Venetian alone. La Quête shows no V1 in matrix declaratives. I suggest that the restrictions on V1 fall out from the innovation of a Force-V2 grammar.

Consider Narrative V1, which features a Null Discourse Operator in Spec-ForceP, linked to non-asserted force. This is entirely compatible with a Force-V2 grammar as this null constituent satisfies the V2 constraint on Force, an observation borne out in Germanic where the Force-V2

\footnotetext{
${ }^{28}$ For the view that functional projections associated with deixis and viewpoint of the speech participants precede the Force-Topic-Focus layer see Sigurðsson (2004, 2011) and Haegeman \& Hill (2013:381-382).
} 
systems in Modern German and Dutch (Bayer 2004; Frascarelli \& Hinterhölzl 2007:113) permit Narrative V1 (Önnerfors 1997; Zwart 1997).

Returning to the V1 we do NOT find in the 'innovative' texts, assume that proTop, which occupies a position within the Topic layer in Fin-V2 systems and gives rise to Rhematic V1 and Topic Continuity V1, can never satisfy Force's EF in Force-V2 systems. The basic intuition is that the null element in question is in some sense defective in the terms of Roberts (2010) and is thus unable to move from the Topic field to the structurally higher Force projection to satisfy V2:

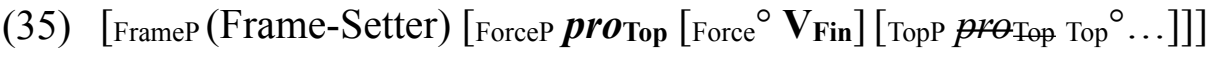

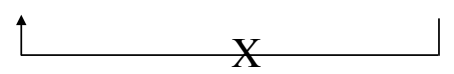

The heavy restrictions or total absence of matrix V1 in Later Old French (Skårup 1975:291; Marchello-Nizia 1980:331; Rouveret 2004:193-195) and Later Old Spanish (Wolfe 2015b) texts is therefore linked to the innovation of Force-V2. In French, the account provides a novel formal account for the long-held observation that Null Subjects/Topics are never realised preverbally from 1200 onwards (Vanelli, Renzi \& Benincà 1985:175; Adams 1987b:12; Roberts 1993:84f; Hulk \& van Kemenade 1995:236; Vance 1995:189, 1997:200). Under the schema in (35) this is due to locality restrictions on this variant of pro, which means it will never be able to raise to the verbal prefield in Force-V2 systems. ${ }^{29}$

Later Old Venetian is a more complex case, where we exceptionally find cases of V1 which do not feature verba dicendi. I suggest that the deictically anchored Null Topic in these contexts raises higher than the Topic-layer, into the Frame-field, where it enters a local relation with projections associated with speech-participants and speaker-deixis (Haegeman 2000:143f; Bianchi 2006:2036-2041; Shlonsky 2009:141-142) as in (36). Venetian therefore demonstrates that although the clausal structure 'available' to the left of the finite verb in Romance Force-V2 systems is

29 This proposal has an additional very desirable effect, as it suggests that once V2 undergoes reanalysis from Fin to a Force-V2 system, Null Subjects or Topics will become unstable in the system as they will only ever be realised in postverbal position. This may go someway towards accounting for why in French (Adams 1987; Vance 1987, 1988, 1997; Roberts 1993, 2007:§1.2.2), Northern Italian Dialects (Vanelli, Renzi \& Benincà 1986; Vanelli 1987; Poletto 1995) and the majority of the Germanic V2 languages (Sigurðsson 1993; Rosenkvist 2009; Axel \& Weiss 2011; Walkden 2013) Null Subjects gradually disappeared from the medieval period onwards, leading some (incorrectly) to claim that there is an inherent incompatibility between a V2 syntax and Null Subjects tout court (Jaeggli \& Safir 1989:33). 
uniform, the inventory of overt and, in this case, null elements which may occupy the projections can vary from language to language: ${ }^{30}$

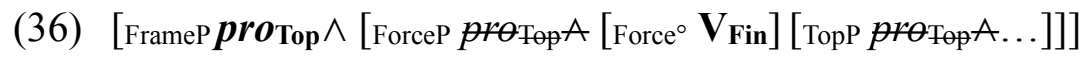

The heavy restrictions on V1 structures in the 'innovative' V2 varieties are therefore linked to the nature of the null elements which can satisfy the V2 constraint. This, in turn, is linked to the high locus of the V2 property on Force.

Thirdly, the Force-V2 hypothesis accounts for changes in the distribution of the particle SI, which we saw has a different distribution in La Quête, compared to the EMR V2 varieties and Later Old Sicilian. In contrast to these more conservative varieties where multiple left-peripheral constituents can precede SI, in La Quête clauses are either SI-initial or Frame-Setter or Hanging Topic-initial (37); exactly the distribution predicted were SI occurring in Spec-ForceP in the innovative grammar:

(37) [FrameP Quant il a ce dit, [ForceP si Force $^{\circ}$ se $=$ redrece... en estant]]

The loss of CP-Information Focus in French, Spanish and Venetian can thus be conceived as the key trigger for reanalysis from a conservative Fin-V2 to an innovative Force-V2 system. This results in a cascade of surface effects, including restrictions on V3, restrictions on V1 and changes in the distribution of SI.

\section{OLD SARDINIAN AND THE LATIN FOUNDATION}

\subsection{The Old Sardinian Condaghes}

The data and analysis above suggest that V2 in Medieval Romance should be conceived as falling into a bi-partite typology, where a Fin-V2 system attested in EMR gives way to a Force-V2 system in French, Spanish and Venetian. We should, in fact, add an additional strand to this typology on the basis of Old Sardinian.

In Wolfe (2015c) evidence is considered from the Old Sardinian condaghes, legal prose texts dating from the 12th century, which have previously been analysed in Lombardi (2007) as attesting a form of VSO grammar. Based on an analysis of clitic placement, adverbial placement, subject positions and the comparative Medieval Romance evidence, it is proposed that Old Sardinian featured 'half of the V2 constraint' in the terms or Roberts (2005:123), as Fin triggers finite verb movement, but

${ }^{30}$ Looking diachronically, it appears therefore that we can postulate an 'upwards' grammaticalisation path in the terms of Roberts \& Roussou (2002) regarding Null Subjects and Topics in Medieval Romance: pro (TP/

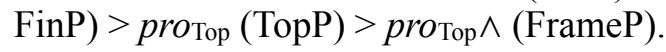


there is no phrasal-movement triggering EF present. This (XP)-VSO grammar thus has an unmarked V1 order (38), in contrast to all other Medieval Romance varieties, but also licenses optional topicalisation or focalisation to the left-periphery, akin to Modern Romance varieties (Rizzi 1997; Benincà 2001; Benincà \& Poletto 2004), yielding V2 (39) and V3* orders:

(38) Posit=ince Bicturu Plana sa parçone sua dessa terra de Collectariu donate.3SG.PST=PRT Bicturu Plana the portion his of-the land of Collecatariu 'Bicturu Plana donated his portion of the land at Collectariu' (Sardinian, SNDT 100, 1115-1200)

(39) Custu totu deti pro=ssa anima sua a sancta Maria de Bonorcantu this all give.3SG.PST for=the soul his to Saint Maria de Bonarcado 'He gave all this for the good of his soul to Saint Maria de Bonarcado' (Sardinian, SMDB $15,1120-1146)$

As noted above Old Sardinian patterns with other EMR varieties in licensing left-peripheral Information Focus (11) and orders where Frame-Setters, Topics and Foci co-occur in the leftperiphery (16).

Taking these facts together, one could extend the synchronic typology of V2 phenomena to postulate that, whilst all other EMR varieties were Fin-V2 systems, Old Sardinian was an exception as a Fin-VSO system. However, a consideration of diachronic changes in subliterary and late Latin suggests that Old Sardinian provides a previously overlooked key to the diachronic evolution in Romance word order in general.

\subsection{The Great Leap from Latin to Romance}

Finite verb-movement into the C-domain cannot be described as a Romance 'innovation' when Classical Latin is taken into account. Although Classical Latin shows a dominant SOV order in the unmarked case (Bauer 1995:94; Polo 2005:400f), V1 orders are employed in a large range of marked contexts, with Wanner (1987:382) viewing 'VSO as a primary alternate pattern' to SOV 'for marked communicative values' in Classical Latin.

Consider the following sentences which are undoubtedly the precursor to the Rhematic V1 discussed above in EMR. V1 rhematic clauses are extensively attested in Classical Latin (Spevak 2004:385; Polo 2005:402; Bauer 2009:278; Horrocks 2011:132):

(40) a. Crescebat interim urbs grow.3SG.PST meanwhile city.NOM

'Meanwhile the city was growing' (Livy, 1.8.3)

b. Erat vallis inter duas acies 
be.3SG.PST valley.NOM between two lines.ACC

'There was a valley between the two battle lines' (BC 2.34)

Additionally, V1 is frequently found cases which correspond to Medieval Romance Topic Continuity V1 in their pragmatico-semantic characteristics. Witness comments by Bauer (2009:277) that V1 in Classical Latin serves to 'push ahead the narrative' or indicate continuity of topic or theme (Linde 1923:160-162; Bolkestein 2000:121; Devine \& Stephens 2006:156-159). The following example is illustrative in this regard and appears to feature a Null Aboutness Topic:

(41) Transfigitur scutum Pulloni.... Avertit hic

pierce.3SG.PASS shield.ACC Pullo.GEN turn.3SG this.NOM

casus vaginam.... Succurrit inimicus illi Vorenus

fall.NOM scabbard.ACC run.3SG enemy.NOM his.DAT Vorenus.NOM

'Pullo's shield is pierced through...This event turns his scabbard aside.... His enemy

Vorenus runs up to him' ( $B G 5.44)$

V1 matrix clauses are also found extensively with imperatives and hortative subjunctives (Marouzeau 1938:81f; Wanner 1987:381-382; Polo 2005:399-400; Bauer 1995:93-94, 2009:277-278; Devine \& Stephens 2006:146-148; Spevak 2010:Ch5; Horrocks 2011:132).

Taken together, these three pieces of evidence suggest that V-to-C movement was already licensed in Classical Latin in marked contexts (Ledgeway 2012:147. Extending our analysis of Rhematic V1 and Topic Continuity V1 to Latin and adopting the standard assumption that V-raising in imperatives targets a projection within a high layer of the CP (Zanuttini 1997:130f; Poletto \& Zanuttini 2003:191; Zeijlstra 2004:181-184), which I take to be Force (Rizzi 1997:283), we can propose that both Force and Top already attract verbs with topic and illocutionary-force-related features in Classical Latin.

Notably, C-related projections can also host BОTH the finite-verb and a fronted phrasal constituent in constructions which Bauer (1995:§4.3, 2009:275-276), building on the earlier insights of Kroll (1918:117) and Möbitz (1924:120f), terms 'syntactically motivated verb-fronting'. These 'accidental V2' constructions which standardly feature an initial-subordinate clause, ablative absolutive, negative expression or adverbial expression bear a striking resemblance to the V2 clauses which predominate in Medieval Romance and are viewed by Ledgeway (2012:153) as 'an unmistakable precursor to the full-fledged V2 syntax of late Latin/early Romance' (cf. also Wolfe 2015a). Consider the following example in this regard, which shows a [TOPIC $+V_{\text {Fin }}$ ordering that has been shown above to become prevalent across the Medieval Romance languages: 
(42) Quod si resilierit,

destinavi illum artificium docere

That if be-restless.3SG.PERF.SBJV decide.1SG.PST him.ACC trade.ACC teach.INF

'if he is restless, I have determined that he will learn a trade' (Petron, 46, 7)

A similar construction which may have been particularly significant in the shift from an SOV grammar permitting marked V-to-C constructions to a full Fin-V2 system concerns 'accidental V2' with copula ESSE 'be'. As argued by Adams (1994a, 1994b) and more recently by Ledgeway (2012:256), ESSE can act as a clitic which adjoins to a 'focal host' within the edge of a colon:

(43) Is est hodie locus saeptus

that.nom=be.3SG today place.NOM guard.PTCP.NOM

'That site is guarded to this day' (Cic. Diu 2.84)

This configuration, as observed as early as Wackernagel (1892), leaves the clitic in colon-second position. Ledgeway (2012:\$5.4.3.1) argues on the basis of more recent theoretical assumptions that ESSE can occupy a position in the C-layer, which I take as a working assumption to be Fin, yielding [FoCUS $\left.+\mathrm{V}_{\text {Fin }}\right]$ strings:

(44) [FrameP [ForceP [TopP [FocP is [FinP est [TP hodie...]]]]]]

Space constraints prevent a thorough survey of the relevant data, but this brief discussion shows clearly that both the key 'ingredients' which were needed to generalise for a reanalysis towards a V2 grammar to take place, namely V-to-C movement and XP-fronting to left-peripheral projections, were already extensively attested in Classical Latin.

Within subliterary Latin, we see evidence of the verb-initial orders becoming a more systematic phenomenon, as in the letters of Terentianus (Clackson \& Horrocks 2007:255), which are widely acknowledged to be reflective of a colloquial Latin register (Adams 1977; Bauer 1995:96): ${ }^{31}$

\section{(45) Uidit Germani liberatam}

see.3SG.PST Germanus.GEN freedwoman.ACC

'she saw Germanus's freedwoman'

With regard to 'accidental V2' structures, Bauer (2009:276) notes they are very frequent in 'the writings of such authors as Petronius, Tertullian and the Itinerarium Egeria, works characterised by popular, everyday language' (cf. Wanner 1987:382; Bauer 1995:102; Salvi 2004:102-111; Clackson \& Horrocks 2007:291; Ledgeway 2012:152-153). Similar observations concern fronting of copula

\footnotetext{
${ }^{31}$ Particularly revealing in this regard are the (statistically small) samples presented in Linde (1923) and Salvi (2004:102) concerning verb placement. Salvi (2004:102) notes that whilst only $10 \%(19 / 181)$ of matrix clauses are V1 in the writings of Cicero, this figure rises to 34\% (85/250) in the Peregrinatio and 53\% (54/101) in the writings of Terentianus. Future research based on a larger sample would be valuable in confirming whether these potentially very revealing tendencies hold up on a wider statistical base.
} 
ESSE, which is more frequent in 'innovative' subliterary or later texts (Ledgeway 2012:257-258). The Focus-initial data is significant in that the immediately adjacent verb signals to the language acquirer that the target of V-to-C movement is a low left-peripheral head, either Foc(us) or Fin.

The significance of this point should be immediately apparent in light of the discussion above, where it was shown that EMR features a system with a 'low' locus of V2. I therefore propose that output generated as a result of copula ESSE-fronting may have had particular significance in triggering a reanalysis which led to the generalisation of V-to-Fin movement in late Latin and Medieval Romance (cf. Salvi 2004). Such argumentation has a very long pedigree in the wider comparative literature, with copula-fronting frequently invoked as an explanation for the rise of V2 systems elsewhere in Indo-European (Hock 1982, 1986:330-340; Eypórsson 1995:175; Faarlund 2010:207).

Clear evidence of the significance of these characteristics towards a reanalysis is found in the Peregrinatio, a 4th century Christian Latin text which is analysed in Wolfe (2015a) as having a (near-)identical matrix clause syntax to Old Sardinian in featuring widespread V1 structures, derived via V-to-C $\mathrm{C}_{\text {Fin }}$ movement (46) and a left-periphery hosting Information Focus (47), or both a Topic and Focus (48):

(46) Praedicant etiam omnes presbyteri preach.3PL also all.NOM priests.NOM

'All the priests also preach' (Peregrinatio XXVI, 1)

(47) et trans vallem apparebat mons sanctus Dei

and across valley.ACC appear.3SG.PST mountain.NOM holy.NOM God.GEN

Syna

Syna

'And across the valley appeared the holy mountain of Sinai' (Peregrinatio I, 1)

(48) [Omnis populus usque ad unum] [cum ymnis] ducent episcopum in Syon all.NOM people.NOM down to one.ACC with hymns.ABL lead.3PL bishop.ACC in Syon 'all the people down to the very last one, lead the bishop down to Syon with hymns' (Peregrinatio XLIII, 2)

Compelling evidence in favour of the hypothesis that verb-movement targets $\mathrm{CP}$ in the Peregrinatio comes from verb-placement relative to deictic temporal adverbs which lexicalise a very high position in the T-layer (Ledgeway in press:\$2.1.1). As highlighted by Salvi (2004:15 n.66), finite verbs in the Peregrinatio consistently follow such adverbials, in contrast to their Classical Latin counterparts, suggesting that verb-movement is targeting the $\mathrm{CP}$ : 
(49) Fecimus ergo et ibi oblationem et orationem...

do.1PL.PST thus and there oblation.ACC and prayer.ACC

'We then made both the oblation and the prayer there' (Peregrinatio IV, 3)

Put clearly, the core characteristics of the Old Sardinian Fin-VSO grammar are already present in what can be termed, somewhat simplistically, as one of the most 'innovative' late Latin texts. This provides supporting evidence that the VSO grammar of Old Sardinian is not an independent development from the medieval period, but instead the retention of a more conservative grammar. I therefore suggest with Salvi $(2004,2011)$ that the V2 syntax found in EMR, was itself an innovation on an earlier VSO syntax. The Old Sardinian evidence is of critical importance, as they appear to be the only medieval texts of length which provide evidence for the continuation of this grammatical system in one language well into the 12 th century.

The proposal is that in the shift from Classical Latin to the system in the 'innovative' Latin texts and Old Sardinian, acquirers reconstructed a grammar which no longer had separate verb movement triggering features on Force, Top and Foc but a single trigger on Fin. This change obeys accepted cross-linguistic principles of acquisition as regards Feature Economy, in demonstrating a shift to a single generalised uninterpretable trigger for verb-movement (Roberts \& Roussou 2002:301; Van Gelderen 2008:297, 2009:93; Biberauer \& Roberts 2015:301). Considerable cross-linguistic support for this proposal comes from work which assumes a similar change to have led to the evolution of the V2 system in Early Germanic (Eypórsson 1995, 2012; Walkden 2014:91).

The question emerging is how the output of a late Latin/Old Sardinian grammar with V-to-Fin movement and optional topicalisation or focalisation was reanalysed as the Fin-V2 grammar, where Fin also bears an EF and merger of a phrasal constituent is no longer optional.

The first factor conditioning this change may have been the analogical extension of a movement-trigger present on $v$ to Fin. Roberts (2007:275) proposes a 'Third Factor' (Chomsky 2005) 'Input Generalisation Principle' for acquisition (see also Poletto 2006a, 2014 for similar ideas). The core idea is that language acquirers will assign similar syntactic properties to functional heads they perceive to form a natural class, unless receiving clear evidence to the contrary in the Primary Linguistic Data (Roberts 2012, 2014:403).

Recall that above we assumed (conservative) Classical Latin to derive pragmatically-neutral OV orders via Comp-to-Spec 'roll-up' movement (Kayne 1994). Ledgeway (2012:270) argues that 
within the classical period this system shifted to a grammar where particular classes of objects moved to the $v \mathrm{P}$-periphery as the result of an movement-trigger on $v{ }^{32}$ :

Figure 2.
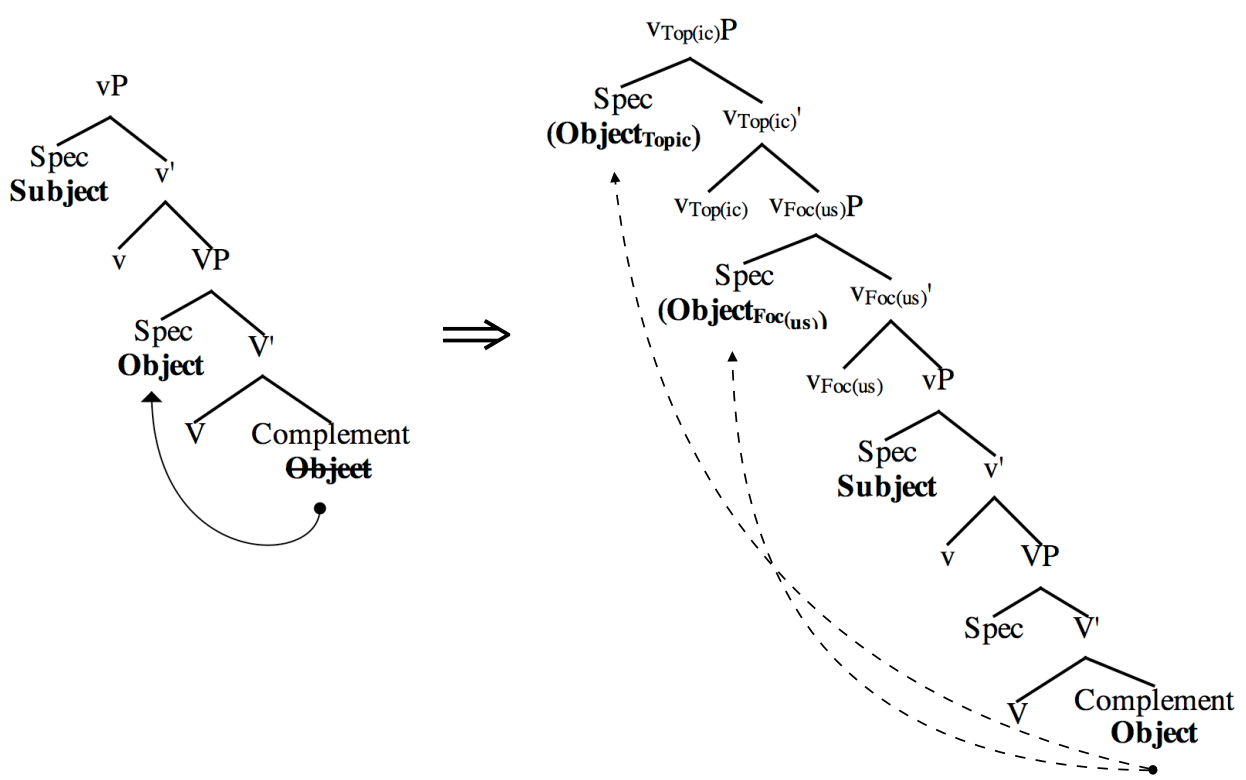

The emergence of the EF on Fin as part of the 'innovative' reanalysis to Fin-V2 can therefore be viewed in new terms grounded in Input Generalisation. Acquirers are extending an EF already associated with $v$ to another verbal head associated with finiteness, namely Fin.

The second factor may also have been one of Feature Economy. In contrast to the Fin-VSO system, where separate, discourse-marked movement triggers were required on heads in the C-layer to trigger optional XP-merger, the 'innovative' Fin-V2 system is more economical in requiring only one movement-trigger on Fin. This is an EF which is 'blind' to the category of XP which is merged, in contrast to the situation in Latin where XPs bearing specific Frame, Topic and Focus features are merged in the $\mathrm{C}$-layer in response to specific triggering features.

These two factors contributed to a change from a Fin-VSO grammar to a Fin-V2 grammar. This would have entailed the reanalysis of V1 structures, derived principally via V-to-Fin movement alone, as featuring an underlying structure with a Null Topic or discourse-operator in a leftperipheral specifier. As shown above, these structures are widely attested in Fin-V2 grammars and

\footnotetext{
${ }^{32}$ Assuming that the fronting to the $v \mathrm{P}$-edge is conditioned by a discourse sensitive EF readily accounts for the fact that fronting of nominals from Classical Latin onwards standardly results in a marked interpretation (see Ledgeway 2012:270-275; Dankaert 2012:Ch6, Ch7). See also Poletto (2014) for extensive discussion of the vP-periphery in Old Italian which still licenses a subclass of OV orders.
} 
as such would not have acted as acquisitional 'blocks' to a Fin-V2 reanalysis. An understanding of the originally unmarked nature of V1 in late Latin, which comes to be reanalysed as a discoursemarked structure in EMR therefore accounts for the extensive attestation of V1 structures in EMR. They are a retention of a structure widespread in the previous grammar, which had a different underlying representation.

Our core proposal is therefore that in the passage from Classical Latin to late Latin and Old Sardinian, previously marked verb-movement was reanalysed as unmarked V-to-Fin movement. An additional reanalysis takes place leading to the Fin-V2 system found in EMR, where previouslymarked topicalisation and focalisation became obligatory in matrix clauses.

\section{CONCLUSION}

\subsection{Summary}

The survey of new comparative data allows us to formulate a new account of the evolution of Romance clausal structure, which entails four distinct stages:

Stage One is attested in the Classical Latin period. Finite verb-movement targets $v$, itself an innovation on a former system where the verb stays in-situ (Ledgeway 2012:270), with V-to-C movement constituting a marked option, when the verb moves to Force, Top and Foc for clausetyping and Information Structure. Left-peripheral topicalisation and focalisation constitute marked word-order alternatives.

Stage Two is attested in subliterary and late Latin texts and is retained in Old Sardinian. Here a reanalysis has taken place where previously-marked verb-fronting is now systematic, unmarked Vto-Fin movement. Topicalisation and focalisation, however, are still not obligatory, yielding a large number of V1 structures.

Stage Three is attested in EMR (11th-12th centuries) and is retained in 13th century Occitan and 14th century Sicilian. Both V-to-Fin movement and topicalisation or focalisation are obligatory, yielding a Fin-V2 grammar. Left-peripheral Information Focus and Topic + Focus orders are uniformly attested.

Stage Four is attested in Later Old French (c. 1200 onwards), Later Old Spanish (c. 1250 onwards) and Later Old Venetian (c. 1300 onwards), where the system is Force-V2. Both verb-movement and obligatory phrasal movement now target the high Force-field and CP-Information Focus is no longer licensed. 
One interesting generalisation emerges from this new diachronic schema: in the passage from Classical Latin to Later Medieval Romance, we witness successive reanalyses where the features triggering finite verb and phrasal merger are successively extended to V-related heads up the clausal spine: 33

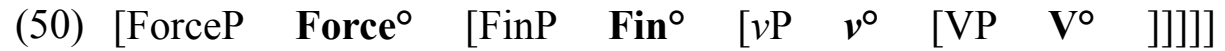

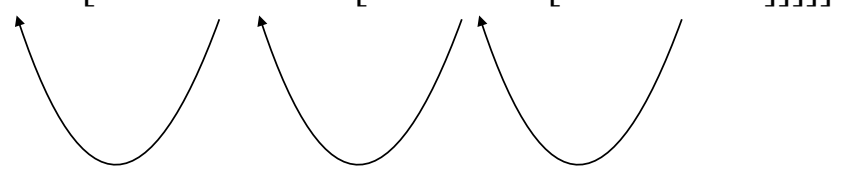

In terms of Input Generalisation, language acquirers are reconstructing grammars where the class of functional heads triggering verb and phrasal movement becomes successively larger to eventually include $\mathrm{V}, v$, Fin and Force.

\subsection{Conclusion and Questions for Future Research}

The overall conclusions of this article are two-fold. The first empirical and theoretical point is that caution should be exercised in treating Medieval Romance V2 or V2 in general as a diachronically homogeneous phenomenon. Rather, the V2 syntax of Romance goes through distinct stages, which are readily identifiable, even in textual evidence which is in many respects challenging to interpret. The second, related, conclusion is that far from being diachronically 'implausible', the passage from the grammatical system attested in Latin textual records to that found in the earliest vernacular documents standardly termed 'Romance' can tentatively be reconstructed as following established properties of syntactic change.

However, a number of issues require further research. Ultimately the confirmation of many of the proposals advanced here lies in the diachronic domain, with particular reference to the syntactic changes the various varieties examined undergo after the medieval period. To choose one example, both Sardinian and Sicilian, which went through a Fin-VSO and Fin-V2 stage respectively, both retain left-peripheral Information Focus today (see Cruschina 2012 for overview). This may suggest that neither went through a Force-V2 stage, a hypothesis which should be testable in the 15th and 16th century Sardinian and Sicilian texts. Likewise, the absence of CP-Information Focus in present day Occitan varieties (Cruschina \& Ledgeway in press:\$2.1) may suggest a previous Force-V2 stage, which again could be tested against the limited, though potentially sufficient, textual records

\footnotetext{
33 As suggested in Wolfe (in press), it may be that no V2 system exists where Foc(us) or Top(ic) always attract the finite verb as these heads are by definition discourse-marked and therefore cannot host the verb in the unmarked case (pace Benincà 2004 et seq. and Poletto 2014). T and Spec-TP would also be excluded from the analogical extension on the grounds that successive cyclic movement moves directly to Spec-FinP via Spec-vP (Chomsky 2009).
} 
from the 14th and 15th centuries. Once this data is established, a wider empirical and conceptual issue still remains unresolved: why the makeup of the left periphery in the varieties showing ForceV2 underwent such dramatic changes, whilst the left peripheral clausal structure of Sardinian and Sicilian has remained essentially unchanged through to the present day. I live tentative answers to this question to future research.

For reasons of space the number of morphosyntactic properties surveyed in the present article has been limited. If as suggested a number of core properties of clausal structure successively change from the Classical Latin period until the 13th and 14th centuries, the prediction may hold that these affect other properties of the grammar. To take one example, given that in a number of the varieties surveyed a series of attested changes in the clitic system (Fontana 1993; Rouveret 2004;

Labelle \& Hirschbühler 2005) and the licensing of null arguments (Vanelli 1987; Roberts 1993; Poletto 1995) seemingly occur either contemporaneously or shortly after the shift from Fin- to Force-V2 outlined above, it may well transpire in future research that the 'cascade' of changes triggered by the loss of Information Focus is even more widespread than claimed here.

\section{PRIMARY SOURCES CITED}

Albanés, J. H. 1879. La Vie de Sainte Douceline. Marseille: Etienne Camoin.

Bonazzi, G. 1997. Il Condaghe di San Pietro di Silki: Testo logudorese inedito dei secoli XI-XIII. Sassari: Dessi.

Brunel, C. 1926. Les plus anciennes chartes en langue provençale: recueil de piéces originales antérieures au XIIIe siècle. Paris: Picard.

Campulu, I. 1989. Libru de lu dialagu di sanctu Gregoriu. Rubbettino: Università di Catania.

Cañas, J. 1988. Libro de Alexandre. Madrid: Ediciones Cátedra.

Curtius, E. R. 1911. Li Quatre livres des Reis. Dresden: Niemeyer.

Delfuoco, S and P. Bernadi. 2005. Sermoni Subalpini. Torino: Centro Studi Piemontesi.

Levi, U. 1904. I monumenti del dialetto di Lio Mazor. Venezia: Visentini.

Knust, Hermann. 1909. Libro de los ejemplos del conde Lucanor y de Patronio. Leipzig: Dr Seele \& Co.

Merci, P. 2001. Il Condaghe di San Nicola di Trullas, Nuoro: Ilisso Edizioni.

Merci, P. 1978. "Il Più Antico Documente Arborense." Medioevo Romanzo V, no. 2-3: 362-83.

Pauphilet, A. 1919. La Quête du Saint Graal. Paris: Champion.

Smith, C. 1972. Poema de mio Cid. Oxford: Clarendon Press.

\section{BIBLIOGRAPHY}

Adams, James N. 1977. The vulgar Latin of the letters of Claudius Terentianus (P. Mich. VIII, 467-72). Manchester: Manchester University Press.

Adams, James N. 1994a. Wackernagel's Law and the Placement of Copula Esse in Classical Latin. Cambridge: The Cambridge Philological Society.

Adams, James N. 1994b. Wackernagel's Law and the Position of Unstressed Pronouns in Classical Latin. Transactions of the Philological Society(92). 103-78. 
Adams, Marianne. 1987a. Embedded Pro. In James Blevins \& Juli Carter (eds.), Proceedings of NELS 16, vol. 1, 1-22.

Adams, Marianne. 1987b. From Old French to the Theory of Pro-Drop. Natural Language \& Linguistic Theory 5(1). 1-32.

Axel, Katrin. 2007. Studies on Old High German syntax left sentence periphery, verb placement and verb-second. Amsterdam; Philadelphia: John Benjamins.

Axel, Katrin \& Helmut Weiss. 2011. Pro-drop in the History of German From Old High German to the modern dialects. In P Gallman \& M Wratil (eds.), Null Pronouns. Berlin: Mouton de Gruyter.

Ayres-Bennett, Wendy. 1996. A history of the French language through texts. London; New York: Routledge.

Bauer, Brigitte. 1995. The emergence and development of SVO patterning in Latin and French: diachronic and psycholinguistic perspectives. New York: OUP.

Bauer, Brigitte. 2009. Word Order. In Philip Baldi \& Pierluigi Cuzzolin (eds.), New Perspectives on Latin Syntax. Vol. 1. Syntax of the Sentence, vol. 1, 241-316. Berlin: Mouton de Gruyter.

Bayer, Josef. 2004. Decomposing the left periphery: Dialectal and cross-linguistic evidence. In Horst Lohnstein \& Susanne Trissler (eds.), The Syntax and Semantics of the Left Periphery, 59-96. Berlin: Walter de Gruyter.

Belletti, Adriana. 1990. Generalised Verb Movement. Turin: Rosenberg \& Sellier.

Belletti, Adriana. 2001. "Inversion" as Focalization. In Aafke Hulk \& Jean-Yves Pollock (eds.), Subject Inversion in Romance and the Theory of Universal Grammar, 60-91.

Belletti, Adriana. 2005. Extended doubling and the VP periphery. Probus 17. 1-35.

Belletti, Adriana. 2008. Structures and Strategies. New York; London: Routledge.

Benincà, Paola. 1983. Un'ipotesi sulla sintassi delle lingue romanze medievali. Quaderni patavini di linguistica 4. 3-19.

Benincà, Paola. 1995. Complement clitics in medieval Romance: The Tobler-Mussafia law. In Ian Roberts \& Adrian Battye (eds.), Clause structure and language change., 325-344. Oxford: OUP.

Benincà, Paola. 2004. The left periphery of Medieval Romance. Studi linguistici e filologici online 2(2). 243-297.

Benincà, Paola. 2006. A detailed map of the left periphery of medieval Romance. In Raffaella Zanuttini (ed.), Crosslinguistic research in syntax and semantics: Negation, tense and clausal architecture, 53-86. Georgetown: Georgetown University Press.

Benincà, Paola. 2013. Caratteristiche del V2 Romanzo. Lingue Romanze Antiche, Ladino Dolomitico e Portoghese. In Ermenegildo Bidese \& Federica Cognola (eds.), Introduzione alla linguistica del mòcheno, 65-84. Turin: Rosenberg \& Sellier.

Benincà, Paola \& C. Poletto. 2004. Topic, focus, and V2. (Ed.) Luigi Rizzi. The Structure of CP and IP. 52-75.

Bentley, Delia. 1999. On the origin of Sardinian àere a plus infinitive. Medioevo Romanzo XXIII(III). 321-358.

Bentley, Delia. 2007. Relazioni grammaticali e ruoli pragmatici: siciliano e italiano a confronto. In Delia Bentley \& Adam Ledgeway (eds.), Sui dialetti italoromanzi: Saggi in onore di Nigel B. Vincent, 48-62. Norfolk: Biddles.

Bianchi, Valentina. 2006. On the syntax of personal arguments. Lingua 116(12). 2023-2067.

Biberauer, Theresa \& Ian Roberts. 2015. Rethinking formal hierarchies: a proposed unification. In Ur Shlonsky (ed.), Beyond Functional Sequence, vol. 10, 295-313.

Bleiberg, German, Maureen Ihrie \& Janet Pérez (eds.). 1993. Dictionary of the Literature of the Iberian Peninsula: A-L. Westport, Conn: Greenwood Press.

Bolkestein, Machtelt. 2000. Discourse organization and anaphora in Latin. In Susan C Herring, Pieter van Reenen \& Lene Schøsler (eds.), Textual Parameters in Older Languages, 107137. Amsterdam: John Benjamins. 
Cardinaletti, Anna \& Ian Roberts. 2002. Clause Structure and X-Second. In Guglielmo Cinque (ed.), Functional Structure in DP and IP, 123-166. Oxford: OUP.

Clackson, James \& Geoffrey C Horrocks. 2007. The Blackwell history of the Latin language. Malden, MA; Oxford: Wiley-Blackwell.

Cognola, Federica. 2013. Syntactic Variation and Verb Second: A German dialect in Northern Italy. Amsterdam; Philadelphia: John Benjamins Publishing Company.

Cruschina, Silvio. 2006. Information focus in Sicilian and the left periphery. In Mara Frascarelli (ed.), Phases of Interpretation, 363-385. Berlin: Mouton de Gruyter.

Cruschina, Silvio. 2011. Focalization and Word Order in Old Italo-Romance. Catalan Journal of Linguistics $10.95-132$.

Cruschina, Silvio. 2012. Discourse-related features and functional projections. Oxford; New York: OUP.

Cruschina, Silvio \& Adam Ledgeway. in press. The Structure of the Clause. In Adam Ledgeway \& Martin Maiden (eds.), The Oxford Guide to the Romance Languages. Oxford: OUP.

D’Alessandro, Roberta, Adam Ledgeway \& Ian G. Roberts (eds.). 2010. Syntactic variation: the dialects of Italy. Cambridge: CUP.

Danckaert, Lieven Jozef Maria. 2012. Latin Embedded Clauses. The left periphery. Amsterdam; Philadelphia: John Benjamins.

Delfuoco, Silvana. 2005. Alla ricerca della lingua perduta. Sermoni Subalpini, 17-35. Torino: Centro Studi Piemontesi.

Devine, A. M \& Laurence D Stephens. 2006. Latin word order: structured meaning and information. Oxford: OUP.

Donaldson, Bryan. 2012. Initial subordinate clauses in Old French: Syntactic variation and the clausal left periphery. Lingua 122(9). 1021-1046.

Duggan, Joseph J. 1989. The Cantar de Mio Cid: Poetic Creation in Its Economic and Social Contexts. Cambridge: CUP.

Ewert, A. 1935. The Strasburg Oaths. Transactions of the Philological Society 34(1). 16-35.

Eytpórsson, T. 1995. Verbal Syntax in the Early Germanic Languages. Cornell University Doctoral Dissertation.

Faarlund, Jan-Terje. 2010. Word Order. In Silvia Luraghi \& Vit Bubenik (eds.), The Bloomsbury Companion to Historical Linguistics, 1-38. London; New York: Bloomsbury.

Fernández Ordóñez, I. 2009. Orden de palabras, tópicos y focos en la prosa alfonsí. Alcanate 6. 139-172.

Fleischman, Suzanne. 1991. Discourse pragmatics and the grammar of Old French: A functional reinterpretation of "si" and the personal pronouns. Romance Philology 44. 251-283.

Fontana, Josep. 1993. Phrase structure and the syntax of clitics in the history of Spanish. University of Pennsylvania Doctoral Dissertation.

Foulet, Lucien. 1919. Petite syntaxe de l'ancien français. Paris: H. Champion.

Frascarelli, Mara. 2000. The syntax-phonology interface in focus and topic constructions in Italian. London: Kluwer Academic Publishers.

Frascarelli, Mara \& Roland Hinterhölzl. 2007. Types of Topics in German and Italian. In S Winkler \& K Schwabe (eds.), On Information Structure, Meaning and Form, 87-116. Amsterdam; Philadelphia: John Benjamins.

Frey, Werner. 2004. Notes on the syntax and pragmatics of German left dislocation. In Horst Lohnstein \& Susanne Trissler (eds.), The Syntax and Semantics of the Left Periphery, 203233. Berlin: Mouton de Gruyter.

Giorgi, Alessandra. 2010. About the Speaker: Towards a Syntax of Indexicality. Oxford: OUP.

Haegeman, Liliane. 1996. Verb second, the split CP and null subjects in early Dutch finite clauses. GenGenP 4(2). 135-175.

Haegeman, Liliane. 2000. Inversion, non-adjacent inversion and adjuncts in CP. Transactions of the Philological Society 98(1). 121-160. 
Haegeman, Liliane. 2012. Adverbial clauses, main clause phenomena, and composition of the left periphery. Oxford; New York: OUP.

Haegeman, Liliane \& Virginia Hill. 2013. The Syntacticization of Discourse. In Raffaella Folli, Christina Sevdali \& Robert Truswell (eds.), Syntax and its Limits. Oxford: OUP.

Hansch, Alexandra. 2014. Germanic Properties in the Left Periphery of Old French: V-to-CMovement. Ottowa: University of Ottowa Doctoral Dissertation.

Haumann, Dagmar. 2007. Adverb Licensing and Clause Structure in English. Amsterdam: John Benjamins.

Herring, Susan C, Pieter Th. van Reenen \& Lene Schøsler (eds.). 2000. Textual parameters in older languages. Amsterdam; Philadelphia: John Benjamins.

Hock, Hans Heinrich. 1982. AUX-Cliticization as a Motivation for Word Order Change. Studies in the Linguistic Sciences 12(1). 91-101.

Hock, Hans Heinrich. 1986. Principles of Historical Linguistics. Berlin: Mouton de Gruyter.

Holmberg, Anders. 2005. Is There a Little Pro? Evidence from Finnish. Linguistic Inquiry 36(4). 533-564.

Holmberg, Anders. 2015. Verb Second. In T Kiss \& A Alexiadou (eds.), Syntax - Theory and Analysis, 242-283. Berlin: Walter de Gruyter.

Holtus, Gunter, Michael Metzeltin \& Christian Schmitt (eds.). 1995. Die Einzelnen Romanischen Sprachen Und Sprachgebiete Vom Mittelalter Bis Zur Renaissance. Walter de Gruyter.

Horrocks, Geoffrey C. 2011. Latin Syntax. In James Clackson (ed.), A companion to the Latin language, 118-143. Chichester, West Sussex; Malden, MA: Wiley-Blackwell.

Huang, C.-T. James. 1984. On the distribution and reference of empty pronouns. Linguistic Inquiry 15. 531-574.

Hulk, Aafke \& Ans van Kemenade. 1995. Verb-Second, Pro-drop, Functional Projections and Language Change. In Ian Roberts \& Adrian Battye (eds.), Clause Structure and Language Change, 227-256. Oxford: OUP.

Jaeggli, Osvaldo \& Ken Safir. 1989. The null-subject parameter and parametric theory. In Osvaldo Jaeggli \& Ken Safir (eds.), The Null Subject Parameter, 1-44. Dordrecht: Kluwer.

Jensen, Frede. 1990. Old French and Comparative Gallo-Romance Syntax. Tübingen: Walter de Gruyter.

Jiménez-Fernández, Ángel J. 2015. When focus goes wild: Syntactic positions for information focus. LingBaW (Linguistics Beyond and Within). 1.

Kaiser, Georg A. 2002. Verbstellung Und Verbstellungswandel in Den Romanischen Sprachen. Max Niemeyer Verlag.

Kayne, Richard. 2000. Parameters and Universals. Oxford: OUP.

Kayne, Richard. 2005. Movement and Silence. Oxford: OUP.

Kayne, Richard. 1994. The antisymmetry of syntax. Cambridge, MA: MIT Press.

Kroll, W. 1918. Anfangstellung des Verbums im Lateinischen. Glotta 9. 112-123.

Labelle, Marie. 2007. Clausal architecture in Early Old French. Lingua 117(1). 289-316.

Labelle, Marie \& Paul Hirschbühler. 2005. Changes in Clausal Structure and the Position of Clitics in Old French. In Montserrat Batllori, Maria-Lluisa Hernanz, Carme Picallo \& Francesc Roca (eds.), Grammaticalization and parametric variation, 149-178. Oxford: OUP.

Labelle, Marie \& Paul Hirschbühler. 2012. Topic and Focus in Old French V1 and V2 Structures. Proceedings of DiGS 13. Philadelphia.

Lambrecht, Knud. 1994. Information structure and sentence form: topic, focus, and the mental representations of discourse referents. Cambridge: CUP.

Ledgeway, Adam. in prep. From Latin to Romance Syntax: The Great Leap. In Paola Crisma \& Giuseppe Longobardi (eds.), The Oxford Handbook of Diachronic and Historical Linguistics. Oxford: OUP.

Ledgeway, Adam. In press. The Verb Phrase. In Giuseppe Longobardi (ed.), The Syntax of Italian. Cambridge: CUP. 
Ledgeway, Adam. 2007. Old Neapolitan word order: some initial observations. In Anna Laura Lepschy \& Arturo Tosi (eds.), Histories and dictionaries of the languages of Italy, 121-49. Ravenna: Longo.

Ledgeway, Adam. 2008. Satisfying V2 in early Romance: Merge vs. Move. Journal of Linguistics 44(02).

Ledgeway, Adam. 2010. Subject Licensing in CP: The Neapolitan Double-subject Construction. In Paola Benincà \& Nicola Munaro (eds.), Mapping the Left Periphery, 257-296. Oxford: OUP.

Ledgeway, Adam. 2011. Philology and linguistics: when data meet theory. Two case studies II: the case of the Placiti cassinesi. Transactions of the Philological Society 109(3). 213-219.

Ledgeway, Adam. 2012. From Latin to Romance: morphosyntactic typology and change. Oxford: OUP.

Ledgeway, Adam. 2015. Parallels in Romance Nominal and Clausal Microvariation. Revue roumaine de linguistique LX(2-3). 105-127.

Ledgeway, Adam \& Alessandra Lombardi. 2005. Verb movement, adverbs and clitic positions in Romance. Probus 17.79-113.

Linde, Paul. 1923. Die Stellung des Verbs in der lateinischen Prosa. Glotta 12. 153-78.

Lombardi, Alessandra. 2007. Posizione dei clitici e ordine dei constituenti della lingua sarda medievale. In Adam Ledgeway \& Delia Bentley (eds.), Sui dialetti italoromanzi: Saggi in onore di Nigel B. Vincent, 133-148. Norfolk: Biddles.

Marchello-Nizia, Christiane. 1985. Dire le vrai: L'adverbe $<<$ si $>>$ en français médieval: Essai de linguistique historique. Geneva: Droz.

Marchello-Nizia, Christiane. 1995. L'évolution du français: Ordre des mots, démonstratifs, accent tonique. Paris: Armand Colin.

Marouzeau, Jules. 1938. L'ordre des mots dans la phrase latine. Vol. 2.3 vols. Paris: Geuthner.

Mathieu, Éric. 2012. The left periphery in Old French. In Deborah Arteaga (ed.), Research in Old French: The state of the art, 327-350. Dordrecht: Springer.

Menéndez Pidal, Ramón. 1926. Orígenes del español: estado lingüístico de la península ibérica hasta el siglo XI. Madrid: Espasa-Calpe.

Mensching, Guido \& Eva-Maria Remberger. in press. Sardinian. In Adam Ledgeway \& Martin Maiden (eds.), The Oxford Guide to the Romance Languages. Oxford: OUP.

Merci, Paolo. 1978. Il più antico documente arborense. Medioevo Romanzo V(2-3). 362-383.

Möbitz, Otto. 1924. Die Stellung des Verbums in den Schriften des Apuleius. Glotta 13. 116-26.

Mussafia, Alfredo. 1888. Enclisi o proclisi del pronome personale atono quale oggeto. Romania 27. 145-146.

Öhl, Peter. 2010. Formal and functional constraints on constituent order and their universality. In Carsten Breul \& Edward Göbbel (eds.), vol. 165, 231-276. Amsterdam: John Benjamins.

Önnerfors, O. 1997. Verb-erst-Delkarativsätze. Grammatik und Pragmatik. Stockholm: Almqvist \& Wiskell International.

Parry, Mair. 1998. The reinterpretation of the reflexive in Piedmontese: "impersonal"SE constructions. Transactions of the Philological Society 96(1). 63-116.

Petrova, Svetlana. 2011. Modeling Word Order Variation in Discourse: On the Pragmatic Properties of VS Order in Old High German. Indo-European syntax and pragmatics: contrastive approaches 3(3). 209-228.

Petrova, Svetlana. 2012. Multiple XP-fronting in Middle Low German root clauses. The Journal of Comparative Germanic Linguistics 15(2). 157-188.

Petrova, Svetlana \& M Solf. 2008. Rhetorical relations and verb placement in early Germanic. A cross linguistic study. In C Fabricius-Hansen \& W Ramm (eds.), "Subordination” vs. "Coordination” in Sentence and Text. A Cross-linguistic Perspective, 333-351. Amsterdam: John Benjamins.

Pinkster, Harm. 1990. Latin Syntax and Semantics. London: Routledge. 
Poletto, Cecilia. 1995. The Diachronic Development of Subject Clitics in North Eastern Italian Dialects. In Adrian Battye \& Ian Roberts (eds.), Clause Structure and Language Change, 295-325. Oxford: OUP.

Poletto, Cecilia. 2000. The Higher Functional Field: Evidence from Northern Italian Dialects. First Edition. Oxford: OUP.

Poletto, Cecilia. 2002. The left-periphery of V2-Rhaetoromance dialects: a new view on V2 and V3. In Sjef Barbiers, Leonie Cornips \& Susanne van der Kleij (eds.), Syntactic Microvariation, 214-242. Amsterdam: Meertens Institute.

Poletto, Cecilia. 2005. "Si" and "e" as CP expletives in Old Italian. In Montserrat Batllori, MariaLluisa Hernanz, Carme Picallo \& Francesc Roca (eds.), Grammaticalization and parametric variation, 206-235. Oxford: OUP.

Poletto, Cecilia. 2006a. Old Italian Scrambling: The Low Left Periphery of the Clause. In Patrick T. Brandt \& Eric Fuss (eds.), Form, Structure, and Grammar: A Festschrift Presented to Günther Grewendorf on Occasion of His 60th Birthday, 209-229. Berlin: Akademie Verlag.

Poletto, Cecilia. 2006b. Parallel Phases: a study of the high and low periphery of Old Italian. In Mara Frascarelli (ed.), Phases of Interpretation, 261-295. Berlin: Mouton de Gruyter.

Poletto, Cecilia. 2013. On V2 Types. In Silvia Luraghi \& Claudia Parodi (eds.), The Bloomsbury Companion to Syntax, 154-164. London: Bloomsbury.

Poletto, Cecilia. 2014. Word Order in Old Italian. Oxford: OUP.

Poletto, Cecilia \& Raffaella Zanuttini. 2003. Making imperatives: evidence from central Rhaetoromance. In Christina Tortora (ed.), The Syntax of Italian Dialects, 175-207. Oxford: OUP.

Pollock, Jean-Yves. 1989. Verb movement, UG and the structure of IP. Linguistic Inquiry 20. 365425.

Pountain, Christopher. 2011. Latin and the Structure of Written Romance. In Martin Maiden, John Charles Smith \& Adam Ledgeway (eds.), The Cambridge History of the Romance Languages. Volume 1: Structures, 606-659. Cambridge: CUP.

Price, Glanville. 1971. The French Language: Past and Present. London: Edward Arnold.

Reenen, Pieter van \& Lene Schøsler. 2000. The Pragmatic Functions of the Old French Particles ainz, apres, donc, lors, or, puis and si. In Susan C Herring (ed.), Textual parameters in older languages, 59-105. Amsterdam; Philadelphia: John Benjamins.

Reis, Marga. 1995. Wer glaubst du hat recht? On So-called Extractions from Verb-Second Clauses and Verb-First Parenthetical Constructions in German. Sprache und Pragmatik 36. 27-83.

Ribeiro, Ilza. 1995. Evidence for a verb-second phase in Old Portuguese. In Adrian Battye \& Ian Roberts (eds.), Clause structure and language change, 110-139. Oxford: OUP.

Rinke, Esther. 2009. Verb placement in Old Portuguese. In Andreas Dufter \& Daniel Jacob (eds.), Focus and Background in the Romance Languages, 309-332. Amsterdam; Philadelphia: John Benjamins.

Rinke, Esther \& Martin Elsig. 2010. Quantitative evidence and diachronic syntax. Lingua 120. 2557-68.

Rivero, María-Lluisa. 1986. Parameters in the typology of clitics in Romance and Old Spanish. Language 62.774-807.

Rizzi, Luigi. 1997. The Fine Structure of the Left Periphery. In Liliane Haegeman (ed.), Elements of Grammar: Handbook of Generative Grammar, 281-338. Dordrecht: Kluwer.

Roberts, Ian. 1993. Verbs and diachronic syntax: a comparative history of English and French. Dordrecht: Kluwer Academic Publishers.

Roberts, Ian. 2005. Principles and parameters in a VSO language: a case study in Welsh. Oxford; New York: OUP.

Roberts, Ian. 2007. Diachronic syntax. Oxford: OUP.

Roberts, Ian. 2010. Agreement and Head Movement. Cambridge, MA: MIT Press. 
Roberts, Ian. 2012. Phases, head movement and second-position effects. In Ángel J Gallego (ed.), Phases developing the framework, 385-440. Berlin; Boston: Mouton.

Roberts, Ian. 2014. Syntactic Change. In Andrew Carnie, Yosuke Sato \& Daniel Siddiqi (eds.), The Routledge handbook of syntax, 391-408. New York: Routledge.

Roberts, Ian \& Anna Roussou. 2002. Syntactic change a minimalist approach to grammaticalization. Cambridge: CUP.

Rosenkvist, Henrik. 2009. Referential null subjects in Germanic: An overview. Working Papers in Scandinavian Syntax 84. 151-180.

Rouveret, Alain. 2004. Les clitiques pronominaux et la périphérie gauche en ancien français. Bulletin de la Société de linguistique de Paris 99. 181-237.

Salvesen, Christine. 2013. Topics and the Left Periphery: A comparison of Old French and Modern Germanic. In Terje Lohndal (ed.), In search of universal grammar: from Old Norse to Zoque, 131-172. Amsterdam: John Benjamins.

Salvesen, Christine \& Kristin Bech. 2014. Postverbal Subjects in Old English and Old French. Oslo Studies in Language 6(1). 201-228.

Salvi, Giampaolo. 2000. La formazione della sistema V2 delle lingue romanze antiche. Lingua e Stile 35.665-692.

Salvi, Giampaolo. 2002. Il problema di si e l'uso riflessivo di essere. Verbum IV(2). 377-398.

Salvi, Giampaolo. 2004. La formazione della struttura di frase romanza: ordine delle parole e clitici dal latino alle lingue romanze antiche. Tübingen: Max Niemeyer Verlag.

Salvi, Giampaolo. 2011. Morphosyntactic persistence. In Martin Maiden, John Charles Smith \& Adam Ledgeway (eds.), The Cambridge History of the Romance Languages, 155-215. Cambridge: CUP.

Salvi, Giampaolo. 2012. On the Nature of the V2 System of Medieval Romance. In Laura Brugè, Anna Cardinaletti, Giuliana Giusti, Nicola Munaro \& Cecilia Poletto (eds.), The cartography of syntactic structures. vol. 7, Functional heads, 103-111. Oxford: OUP.

Santorini, Beatrice. 1989. The Generalization of the Verb-Second Constraint in the History of Yiddish. University of Pennsylvania PhD Dissertation.

Scremin, Maria Francesca. 1984. La struttura della frase nella lingua poetica siciliana. University of Padua Laurea Thesis.

Sheehan, Michelle. 2016. Subjects, null-subjects and expletives in Romance. In Susann Fischer \& Christoph Gabriel (eds.), Manual of Grammatical Interfaces in Romance. Berlin: Mouton de Gruyter.

Shlonsky, Ur. 2009. Hebrew as a Partial Null Subject Language. Studia Linguistica 63. 133-157.

Sigurðsson, Halldór Ármann. 1989. The syntax of Person, Tense and speech features. University of Lund Doctoral Dissertation.

Sigurðsson, Halldór Ármann. 1990. V1 declaratives and verb raising in Icelandic. (Ed.) Joan M. Maling \& A Zaenen. Syntax and Semantics 24. 41-69.

Sigurðsson, Halldór Ármann. 1993. Argument-drop in old Icelandic. Lingua 89(2-3). 247-280.

Sigurðsson, Halldór Ármann. 2004. The syntax of Person, Tense and speech features. Italian Journal of Linguistics 16. 219-251.

Sigurðsson, Halldór Ármann. 2011. Conditions on Argument Drop. Linguistic Inquiry 42(2). 267304.

Sigurðsson, Halldór Ármann \& Joan M. Maling. 2010. The Empty Left Edge Condition. In Michael Putnam (ed.), Exploring Crash-Proof Grammars, 57-84. Amsterdam; Philadelphia: John Benjamins.

Simonenko, A \& Paul Hirschbühler. 2012. Placement de clitiques dans les propositions V1 et évolution de la structure de la proposition en ancien français. In M Dufresne (ed.), Typologie, ordre des mots et groupe verbal en français médiéval, 11-53. Laval, Québec: Les Presses de L'Université Laval. 
Sitaridou, Ioanna. 2005. A corpus-based study of null subjects in Old French and Old Occitan. In Claus D. Putsch, Johannes Kabatek \& Wolfgang Raible (eds.), Corpora and Diachronic Linguistics, 359-374. Tübingen: Narr.

Sitaridou, Ioanna. 2011. Word order and information structure in Old Spanish. Catalan Journal of Linguistics 10.159-184.

Sitaridou, Ioanna. 2012. A comparative study of word order in Old Romance. (Ed.) Anne Carlier, Béatrice Lamiroy \& Walter De Mulder. Folia Linguistica 46(2 "The pace of Grammaticalisation in Romance"). 1-51.

Skårup, Povl. 1975. Les premières zones de la proposition en ancien français. Copenhagen: Akademisk Forlag.

Smith, Colin. 1972. Poema de mio cid. Oxford: Clarendon Press.

Spevak, Olga. 2004. Verb-subject order in Latin: The case of existential and locative sentences. Classica et Mediaevalia. Revue danoise de philologie et d'histoire 55. 381-396.

Spevak, Olga. 2010. Constituent order in classical Latin prose. Amsterdam; Philadelphia: John Benjamins.

Steiner, B. Devan. 2014. The Role of Information Structure in the Loss of Verb-Second in the History of French. Boston, Massachusetts: University of Indiana, Bloomington PhD Thesis.

Stussi, Alfredo. 1965. Testi veneziani del Duecento e dei primi del Trecento. Pisa: Nistri-Lischi.

Thurneysen, Rudolf. 1892. Die Stellung des Verbums in Altfranzösischen. Zeitschrift für Romanische Philologie 16. 289-307.

Tobler, Adolf. 1875. De l'ordre des mots dans Chrétien de Troyes. Vermischte Beiträge zur französischen Grammatik 5.395-414.

Vance, Barbara. 1987. The Evolution of Prodrop in Medieval French. Cornell, ms.

Vance, Barbara. 1988. L'évolution de pro-drop en français médiéval. Revue québécoise de linguistique théorique et appliquée 7. 85-109.

Vance, Barbara. 1993. Verb-first declaratives introduced by et and the position of pro in old and middle French. Lingua 89(2-3). 281-314.

Vance, Barbara. 1995. On the decline of verb movement to Comp in Old and Middle French. In Adrian Battye \& Ian Roberts (eds.), Clause structure and language change, 173-199. Oxford: OUP.

Vance, Barbara. 1997. Syntactic change in medieval French: verb-second and null subjects. Dordrecht: Kluwer.

Vance, Barbara, Bryan Donaldson \& B. Devan Steiner. 2009. V2 loss in Old French and Old Occitan: The role of fronted clauses. In Sonia Colina, Antxon Olarrea \& Ana Maria Carvalho (eds.), Romance Linguistics 2009. Selected papers from the 39th Linguistic Symposium on Romance Languages (LSRL), Tuscon, Arizona, 301-320. Amsterdam: John Benjamins.

Vanelli, Laura. 1987. I pronomi soggetto nei dialetti italiani settentrionali dal Medio Evo ad oggi. Medioevo Romanzo XIII. 173-211.

Vanelli, Laura, Lorenzo Renzi \& Paola Benincà. 1986. Tipologia dei pronomi soggetto nelle lingue romanze medievali. Quaderni Patavini di Linguistica 5. 49-66.

Van Gelderen, Elly. 2008. Where did Late Merge go? Grammaticalization as feature economy. Studia Linguistica 62(3). 287-300.

Van Gelderen, Elly. 2009. Feature Economy in the Linguistic Cycle. In Paola Crisma \& Giuseppe Longobardi (eds.), Historical Syntax and Linguistic Theory, 93-109. OUP.

Vincent, Nigel. 2014. Similarity and diversity in the evolution of Italo-Romance morphosyntax. In Paola Benincà, Adam Ledgeway \& Nigel Vincent (eds.), Diachrony and Dialects, 1-19. Oxford: OUP.

Virdis, Maurizio. 2004. Le prime manifestazioni della scrittura nel cagliaritano. In Barbara Fois (ed.), Judicalia, Atti di Seminario. Cagliari. 14 dicembre 2003., 45-54. Cagliari: CUEC.

Wackernagel, Jacob. 1892. Über ein Gesetz der indogermanischen Wortstellung. Indogermanische Forschungen 1.333-436. 
Walkden, George. 2013. Null subjects in Old English. Language Variation and Change 25(02). $155-178$.

Walkden, George. 2014. Syntactic reconstruction and Proto-Germanic. New York: OUP.

Walkden, George. 2015. Verb-third in early West Germanic: a comparative perspective. In Theresa Biberauer \& George Walkden (eds.), Syntax Over Time, 236-248. Oxford: New York: OUP.

Wanner, Dieter. 1987. The development of Romance clitic pronouns: from Latin to Old Romance. Berlin; New York: Mouton.

Westergaard, Marit. 2009. The Acquisition of Word Order: Micro-cues, information structure, and economy. Amsterdam: John Benjamins.

Wolfe, Sam. 2015a. Medieval Sardinian: New Evidence for Syntactic Change from Latin to Romance. In Dag T.T. Haug (ed.), Historical Linguistics 2013: Selected papers from the 21 st International Conference on Historical Linguistics, Oslo, 5-9 August 2013, 303-324. (Current Issues in Linguistic Theory 334). Amsterdam; Philadelphia: John Benjamins. https://benjamins.com/\#catalog/books/cilt.334.16wol/details.

Wolfe, Sam. 2015b. The nature of Old Spanish verb second reconsidered. Lingua 164, Part A. 132155. doi:10.1016/j.lingua.2015.06.007.

Wolfe, Sam. 2015c. The Old Sardinian Condaghes. A Syntactic Study. Transactions of the Philological Society 113(2). 177-205. doi:10.1111/1467-968X.12046.

Wolfe, Sam. 2015d. Verb-Initial Orders in Old Romance: A Comparative Account. Revue roumaine de linguistique LX(2-3). 148-172.

Wolfe, Sam. In Press. On the Left Periphery of V2 Languages. Rivista di Grammatica Generativa: Selected Papers from the 41st Incontro di Grammatica Generativa.

Wright, Roger. 1991. Latin and the Romance languages in the early Middle Ages. London; New York: Routledge.

Zanuttini, Raffaella. 1997. Negation and Clausal Structure: A Comparative Study of Romance Languages. New York: OUP.

Zeijlstra, Hedde H. 2004. Sentential Negation and Negative Concord. Utrecht: University of Amsterdam PhD Dissertation.

Zimmerman, Michael. 2014. Expletive and Referential Subject Pronouns in Medieval French. Berlin; New York: Mouton de Gruyter.

Zubizarreta, Maria Luisa. 1998. Prosody, focus, and word order. Cambridge, MA: MIT Press.

Zwart, C. Jan-Wouter. 1997. Morphosyntax of Verb Movement: A Minimalist Approach to the Syntax of Dutch. Dordrecht: Kluwer. 